\title{
ASIAN-AFRICAN LEGAL CONSULTATIVE COMMITTEE ANNUAL SURVEY OF ACTIVITIES 1993-1994, including the work of its Thirty-third Session, held in Tokyo, 17-21 January $1994^{*}$
}

\section{M.C.W. Pinto**}

1. Membership and organization

Paragraphs

2. Questions under consideration by the International Law

Commission

2.1 State responsibility

2.2 Draft Code of Crimes against the Peace and Security of Mankind: the establishment of an International Criminal Court

2.3 Law of the non-navigational uses of international watercourses

2.4 International liability for injurious consequences arising out of acts not prohibited by international law

$2.5 \quad$ New topics

3. Legal problems referred to the Committee by participating States 20-43

3.1 The status and treatment of refugees

3.2 Law of international rivers

3.3 Law of the sea

4. Matters of common concern having legal implications

4.1 The United Nations Conference on Environment and Development: follow-up

4.2 United Nations Decade of International Law

4.3 World Conference on Human Rights: follow-up

4.4 'Agenda for Peace'

4.5 Debt burden of developing countries

4.6 Trade law matters

5. Other matters

Deportation of Palestinians in violation of international law

\footnotetext{
* The account of the main activities of the Committee and the main views expressed during or in connection with the Committee's Thirty-third Session has been adapted from (the unpublished version of) the Secretariat's Report of the Thirty-third Session ("Report"). Since 1994 the Secretariat has started publication of "Asian-African Legal Consultative Committee: Report and Selected Documents of the [...] Session".
}

** General Editor.

Asian Yearbook of International Law, Volume 4 (Ko Swan Sik et al., eds.; 90-411-0872-6 ${ }^{\circledR} 1995$ Kluwer Law International; printed in Great Britain), pp. 333-404 


\section{MEMBERSHIP AND ORGANIZATION}

1. There were forty-three Members of the Committee on 17 January 1994: Bangladesh, China, Cyprus, Egypt, Gambia, Ghana, India, Indonesia, Iran, Iraq, Japan, Jordan, Kenya, Democratic People's Republic of Korea, Republic of Korea, Kuwait, Libya, Malaysia, Mauritius, Mongolia, Myanmar, Nepal, Nigeria, Oman, Pakistan, Palestine, Philippines, Qatar, Saudi Arabia, Senegal, Sierra Leone, Singapore, Somalia, Sri Lanka, Sudan, Syria, Tanzania, Thailand, Turkey, Uganda, United Arab Emirates, and Yemen Arab Republic. Botswana is an Associate Member.

2. The Thirty-third Session of the Committee was held in Tokyo from 17-21 January 1994 at the invitation of the Government of Japan. His Excellency Mr. KUNIHIKo SAITO, Vice-Minister for Foreign Affairs of Japan, delivered the inaugural address, and H.E. Mr. AKIRA MIKAZAKI, Minister of Justice, delivered an address of welcome. Mr. CHUSEI YAMADA, Ambassador of Japan to India and currently a Member of the International Law Commission, was elected President and Mr. NAJEeb MohaMmed AL-NAuIMI, Minister Legal Adviser to H.H. The Heir Apparent of Qatar, was elected Vice-President. Mr. RAUL I. GoCo (Philippines) was elected chairman of a Special Meeting on "Developing Institutional and Legal Guidelines for Privatization and Postprivatization Regulatory Framework" held during the Session, and Mr. RALPH W. OCHAN (Uganda) was elected Rapporteur of the Special Meeting. The Secretary-General of the Committee, Mr. FRANK X. NJENGA, and the members of the AALCC Secretariat were responsible for the organization of the Session.

3. The President declared that, at its Thirty-second Session in Kampala, the Committee had decided to hold its Thirty-fourth Session in Doha, in March 1995. As earlier reported (3 AsYIL, p.260), the Committee at its Kampala Session also decided to accept the offer of the State of Qatar "to host the Headquarters of the AALCC in Doha".

4. Mr. FranK X. NJENGA (Kenya) having served as Secretary-General for two consecutive terms of three years each as permitted by Rule 20(i) of the Statutory Rules of AALCC, the Committee, at the Sixth Plenary Meeting of the Session on 21 January 1994 unanimously elected Mr. TANG CHENGYUAN, Deputy Director-General, Department of Treaty and Law of the Ministry of Foreign Affairs of China, as Secretary-General for a three-year term 
commencing 10 May 1994. (Report, pages 151 and 258; Doc. No. AALCC/ XXXIII/TOKYO/94/19).

\section{QUESTIONS UNDER CONSIDERATION BY THE INTERNATIONAL LAW COMMISSION}

5. The Committee had before it a Secretariat document entitled Report on the Work of the International Law Commission at its Forty-fifth Session (Doc. No. AALCC/XXXIII/ TOKYO/94/1) containing surveys of the Commission's work on four topics, viz. State responsibility, Draft Code of Crimes against the Peace and Security of Mankind: the establishment of an International Criminal Court, Law of the non-navigational uses of international watercourses, and International liability for injurious consequences arising out of acts not prohibited by international law.

\subsection{State responsibility}

6. The delegate of Japan emphasizing the importance of the topic, urged the Commission to find ways to ensure more rapid progress in the drafting of articles dealing with it. Referring to the complexity of the issues involved, the delegate of China said his government would make an in-depth study and submit detailed comments only after the Commission's first reading of the whole topic had been completed. The delegate of India said his delegation was opposed to recourse to reprisals as they were iniquitous and only led to abuse of powers. In his view, counter-measures involved unilateral determination, and subjection of such counter-measures to peaceful settlement procedures was not likely to resolve the issues which could arise. The delegate of Sri Lanka shared the concern expressed regarding the desirability of formulating a legal regime of unilateral counter-measures, given the inherent dangers of its abuse. He wondered whether dispute settlement procedures would provide an effective remedy in situations where there had been resort to unlawful or disproportionate counter-measures. 


\subsection{Draft Code of Crimes against the Peace and Security of Mankind: the establishment of an International Criminal Court}

7. The delegate of Japan said that the international community now felt the need for a new mechanism or instrument that would ensure the rule of law, and recalled the recent establishment by the Security Council of an international tribunal for the prosecution of persons responsible for serious violations of international humanitarian law committed in the territory of the former Yugoslavia as an enforcement measure under Chapter VII of the Charter of the United Nations. Referring to the draft Statute of the International Criminal Court, he said that an approach that would permit optional acceptance of the Court's jurisdiction would be likely to facilitate acceptance of the Statute by a larger number of States, which was the main condition to be satisfied.

8. The delegate of China said that, should there be the need to establish an International Criminal Court, the many highly complex and politically sensitive issues involved would have to be resolved with care and caution so as to ensure the feasibility of the Court and its acceptance by all States. A fundamental question was why a State should surrender its criminal jurisdiction over a case if it had the will and judicial capability to exercise such jurisdiction. In his view, the proposals of the Commission were relatively realistic and balanced, although some draft articles would need further consideration and elaboration.

9. The delegate of India observed that many issues including those relating to the proposed Court's jurisdiction and the types of offences with which it would deal, were to be considered at the Commission's forthcoming session. Recalling that there was now a trial mechanism for dealing with offences in the former Yugoslavia, and that it did not appear urgent to set up other ad hoc courts, he said his delegation would prefer the establishment of an institution of a permanent nature.

10. The delegate of Turkey, after an analysis of the draft Statute, observed that the question whether the proposed Court would be a judicial organ of the United Nations, or whether it should be linked to the United Nations in some manner to be prescribed in its Statute, remained unsettled.

11. Commending the Commission's approach as being pragmatic and flexible, the delegate of Sri Lanka recalled that there were several aspects of the 
proposed Court that would need to be further clarified. Expressing the view that the concept "crimes under general international law" lacked specificity adequate to confer jurisdiction on courts, he suggested that the proposed Court's jurisdiction be confined to offences under the conventions listed in draft Article 22, at least until elaboration and general acceptance of a Code of Crimes against the Peace and Security of Mankind. His delegation was also of the view that the UN Convention against Illicit Traffic in Narcotic Drugs and Psychotropic Substances (1988) should be treated on the same level as other international conventions as constituting international crimes under draft Article 22, rather than as undesirable conduct in terms of Article 26. The Statute's provisions on surrender of persons should be clarified taking into account their relationship to any such existing obligations under bilateral or multilateral treaties.

\subsection{Law of the non-navigational uses of international watercourses}

12. The delegate of Syria, recalling that his delegation had presented its comments on the International Law Commission's draft articles to the Committee at its Islamabad Session in 1992, declared that the volume of a watercourse should under no circumstances be reduced below the sanitary discharge level needed for the river bed concerned. In his opinion, the existence of a general obligation among watercourse States to co-operate, meant that those States should agree upon how the particular watercourse could be shared reasonably and equitably. Provisions on exchange of data and information should be implemented through 'joint committees', and should include information on reservoir operations of the States concerned before and after the conclusion of an agreement on use of the international watercourse concerned.

13. The delegate of China observed that it would be difficult to develop a set of norms regulating the non-navigational uses of international watercourses, since the topic touched upon a variety of issues important to each watercourse State, such as those connected with the national economy, the livelihood of its peoples, ecological balance and environmental protection. As international watercourses varied greatly in terms of hydrographic, geological, climatic and geological factors, such issues engaged the fundamental interests of the States concerned, and could reveal contradictions among them.

14. The delegate of Turkey said that the diversity of characteristics of international rivers, and of the circumstances associated with them should be 
taken into account in formulating the draft articles. He urged that law and policy reflecting national concerns regarding such watercourses should be integrated with global regimes aimed at preservation of the environment and sustainable development.

15. The delegate of Japan said that the question of what form should ultimately be given to the draft articles being prepared by the Commission on this topic should be taken up at a later stage of the work.

\subsection{International liability for injurious consequences arising out of acts not prohibited by international law}

16. The delegate of China agreed with the Commission's decision to give priority to consideration of the element of 'prevention', since this approach reflected the current tendency in international environmental legislation. He urged that in formulating preventive measures the Commission should take fully into account the special needs of the developing countries. The delegate of Japan, observing that this topic was of particular importance to the development of international environmental law, said his delegation expected that the Commission at its next session would produce draft articles on 'prevention', and take decisions on the next stage of its work on the topic.

17. The delegate of Turkey emphasized the importance of establishing a global legal regime which would effectively protect mankind and the environment from the rapidly accelerating negative consequences of economic development.

\subsection{New topics}

18. Some delegates welcomed the Commission's selection of the "Law and practice relating to reservations to treaties", and "State succession and its impact on the nationality of natural and legal persons" as new topics for its long-term programme of work.

\section{Decision}

19. Discussion of this item (Report, pages 86-96; see also pages 37-55) was followed by adoption of an essentially procedural decision (Report, pages 2256). 


\section{LEGAL PROBLEMS REFERRED TO THE COMMITTEE BY PARTICIPATING STATES}

\subsection{The status and treatment of refugees}

20. The Committee had before it the following documents prepared by the Secretariat: "Model legislation on the status and treatment of refugees" (Doc. No. AALCC/ XXXIII/TOKYO/94/3); and "Establishment of 'Safety Zones' for displaced persons in the country of origin" (Doc. No. AALCC/XXXIII/ TOKYO/94/4).

Document TOKYO/94/3 is based on the view that the preparation of a model law for incorporation into national legislation would be more effective in securing protection for refugees than further work on international law standards and principles which may lack enforcement procedures. The Secretariat offers a revised list of main headings of draft model legislation (compare the more detailed list presented to the Committee's Thirty-second Session, 3 AsYIL p.265) and focuses on some issues involved in defining the term 'refugee' or the category of persons entitled to protection under such legislation:

“. . .

17. Historically, the term refugee was used in various instruments prior to 1951 to refer to the ethnic or territorial origins of different uprooted groups, and to their loss of national protection. There was in these instruments no reference to persecution in the sense that this term is currently employed. For example, various pre-war instruments or arrangements provided for the issuance of documents to 'Russian refugees' (in 1922) and to 'Armenian refugees' (1924) - in both cases referring to their national origin and to their loss of protection by the Governments of the USSR or of the Turkish Republic respectively. These provisions were, in 1928, extended to 'Turkish, Assyrian and Assyro-Chaldean refugees', followed by a Convention for 'refugees coming from Germany', in 1938, which likewise referred to persons of Germany origin lacking protection of the German Government.

18. The first formal reference to persecution as part of the refugee definition came in the 1946 Constitution of the International Refugee Organisation (hereinafter called the IRO), a temporary specialized agency of the United Nations and the predecessor of UNHCR. Paragraph 7 (a)(i) of Section C of the Constitution of the IRO referred to a "persecution or fear, based on reasonable grounds owing to race, religion, nationality, or political opinions" as being a valid objection to repatriation. Paragraph 3 of Section A of Part I extended IRO's competence to the 'victims of Nazi persecution' still within 
their country of origin. IRO's Constitution also made reference for the first time to 'displaced persons' as well as refugees - a concept which came to be extensively applied to UNHCR's mandate.

19. Thereafter the United Nations Declaration of Human Rights in 1948 alluded to everyone's right to seek asylum from 'persecution', without further defining the term, and the General Assembly employed the term 'well-founded fear of persecution' for specified reasons as the central criterion in dertermining the ambit of UNHCR's Statute.

20. This definition was essentially repeated in the 1951 Convention Relating to the Status of Refugees while its application was limited to victims of persecution as a result of events occurring before January, 1951. The extent and scope of the term 'refugee' was, however expanded in as much as it included 'membership of a social group' as one of the possible causes of persecution. States parties could also, if they desired, restrict the causative events to those occurring in Europe. The 1967 Protocol to the Convention removed both the temporal limitation as well as the optional geographic limitation from this definition.

21. The definitions of the term 'refugee' in the Convention and Protocol have, since 1967, remained unchanged, although it may be recalled that Recommendation E of the Final Act of the Conference of Plenipotentiaries which adopted the Convention in 1951, urged all States parties to extend its benefits as far as possible to persons who did not fall within its strict ambit. While this, of course, is not binding on States it is indicative of the general agreement, at that time, of the need for a liberal interpretation of the term refugee, by States in determining who should receive international protection.

22. This need also became very apparent in regard to UNHCR's activities, and by the 1960s the need for groups outside the original statutory definition to be assisted was clear, particularly in the wake of the General Assembly Resolution the Granting of Independence to Colonial Peoples and independence movements in Africa.

23. Consequently there were a series of General Assembly resolutions, extending over the next two decades, which formally endorsed the High Commissioner's involvement with a much broader category of exiles. Thus in 1959 the General Assembly requested the High Commissioner to use his 'good offices' to transmit contributions to "refugees not within the competence of the United Nations" (without defining this phrase further). Then from 1961 to 1963 a series of General Assembly resolutions endorsed UNHCR activities for regugees within the High Commissioner's mandate "or those for whom he extends his good offices". 
24. This liberalizing trend was reinforced in 1969 by the OAU Convention Governing the Specific Aspects of Refugee Problems in Africa, which added to the statutory refugee definition an important expansion of the term in so far as it applied in Africa, viz., that :

\begin{abstract}
“'Refugee' shall also apply to every person who, owing to external aggression, occupation, foreign domination or events seriously disturbing public order in either part or the whole of his country of origin or nationality, is compelled to leave his place of habitual residence in order to seek refuge in another place outside his country of origin or nationality".
\end{abstract}

This expanded definition remains the most formal extension of the refugee concept accepted by Governments, and has, following proposals made at the Arusha Conference on Refugees in Africa in 1979, been endorsed by the General Assembly as applying to UNHCR's activities in the African continent.

25. At the same time the General Assembly continued to request UNCHR to undertake programmes generally benefitting persons outside the ambit and scope of the original definition of the term refugee. The High Commissioner was requested, in 1972, to continue to participate, at the invitation of the Secretary-General, in those humanitarian endeavours of the United Nations for which UNHCR had particular expertise and experience. In the following year he was requested, by the General Assembly, to continue his assistance and protection activities for refugees within his mandate as well as for those "for whom he extends his good offices or is called upon to assist".

26. The next reference to 'displaced persons' came in 1975, with a General Assembly resolution requesting the High Commissioner to continue his assistance to Indochinese 'displaced persons', a category which was to appear in every resolution endorsing the Office's activities for the next five years. Particularly important among these was the General Assembly resolution 31135 which endorsed ECOSOC resolution 2011 of that year, in which UNHCR's assistance to displaced persons, defined as "the victims of man-made disasters requiring urgent humanitarian assistance", in addition to its aid to refugees was approved. The term has remained undefined except for the ECOSOC resolution mentioned above, although it has been suggested that the 'man-made disasters' referred to in this definition might appropriately be described as those outlined in the expanded OAU definition. Nevertheless UNHCR's activities certainly benefit many more 'displaced persons' than strictly defined refugees: the millions of uprooted victims of external wars or civil strife normally falling within this category.

27. The application of the concept of displaced persons led to an acceptance of international responsibility for specified national or ethnic groups, similar to that reflected in the pre-1951 refugee instruments. Concurrently, however, 
individual eligibility procedures have continued to be applied, particularly by traditional resettlement or receiving countries, often more strictly than in the past. Ironically this resulted partly from continuing pressure on third countries to provide resettlement opportunities for displaced persons granted temporary asylum, particularly in South East Asia.

28. The liberal use of the displaced persons concept and prima facie group determination procedures in countries of first asylum, while essential to enable prompt and proper assistance to be given, has also led to a number of other difficulties in practice. One of these is how to sift out those not entitled to receive help - such as economic migrants - when individual screening is not done, or how to exclude those displaced persons who are not entitled to protection, such as war criminals or armed activists. As regards economic migrants it must be observed that there is no international instruments or authority to deal with such persons, and traditionally, they have been subjected to the juridical process of emigration-cum-immigrationrather than the customary principles of non-refoulement and asylum. Experience has shown that the plight of these peoples could be such as to make their lives unbearable in the country of origin and those conditions could be so serious as to amount to persecution or a "well founded fear of persecution". It is for consideration whether the proposed legislation should seek to include and cover economic refugees. In providing international protection for economic migrants, solutions must be found in dimensions other than those of the causative end of the outflow and at the recipient end of the outflow.

29. A new turn was given to the concept of international protection when the ECOSOC referred to persons "who have been forced to flee from their homes suddenly or unexpectedly in large numbers; as a result of armed conflict, internal strife, systematic violations of human rights or natural or man-made disasters, and who are within the territory of their own country." It would have been observed that this definitin of internally displaced persons does not conform to the traditional understanding of the term of refugee i.e. an asylum seeker who has actually been granted or has received protection outside his own country of origin or habitual residence, to whom asylum has been granted from the authorities of the country of origin and is recognized as a person who is entitled to enjoy certain rights under international law. This is by reason of the fact that in customary international law a refugee is a person who is outside the protection of the State or is unwilling to seek the protection of the State of his nationality or habitual residence. There is thus a need to consider the distinction to be drawn between the terms to be employed and the scope to be given to the Model Legislation. The Committee may wish to consider whether or not the Secretariat should seek to incorporate definitions of some key terms to be employed in the proposed model legislation. The future work 
of the Secretariat on model legislation on rights and duties of refugees would now rest on the directives which the Committee's Tokyo Session may give.

30. The Secretariat of the Committee has managed with assistance of the Office of the UNHCR to obtain all the existing national legislations pertaining to refugees. The Secretariat is grateful to the UNHCR for assistance in making copies available to AALCC through the officers of the 'CDR' division, Geneva. The Secretariat of the AALCC is in the process of a thorough examination of these municipal instruments and has been working towards an expanded definition of the term 'Refugee'. The Secretariat, however, is of the view that the question of the expansion of the definition of the term requires to be discussed further. The Committee at its forthcoming Session may wish to give consideration to the extent and scope of the key term around which the proposed model legislation is to be drafted. The guidelines that the Committee may wish to furnish would enable the Secretariat to fulfill its mandate at an early date.

..."

21. Document TOKYO/94/4, having recalled the scale of the difficulties involved in dealing with refugees in general and 'internally displaced persons' in particular, re-states "thirteen principles which could furnish a framework for the establishment of Safety Zones in the country of origin" (see 3 AsYlL p.265), and goes on to discuss specific issues to be resolved, including the rôle of the United Nations High Commission for Refugees in such zones:

“. . .

\section{INTRODUCTION}

The Secretary General of the United Nations in his Report on Preventive Diplomacy, Peacemaking and Peacekeeping, entitled 'An Agenda for Peace', inter alia, observed that "Poverty, disease, famine, oppression and despair abound to produce 17 million refugees, 20 million displaced persons and massive migrations of peoples within and beyond national, borders". [footnote: See Boutros-Ghali, An Agenda for Peace Preventive Diplomacy, Peacemaking and Peacekeeping. Report of the Secretary-General pursuant to the Statement adopted by the Summit Meeting of the Secretary Council on 31 January 1992 (United Nations, New York 1992) para 13 at page 17]. It is now estimated that the number of refugees is 19 millions and that internally displaced persons are estimated to be more than 20 millions. The most recent are to be found in Afghanistan, Iraq (the Kurds), Cambodia, former Yugoslavia and some members of the Commonwealth of Independence States (CIS) which have been ravaged by ethnic wars. Somalis have also been uprooted due to civil war. The worst drought of the century in several countries has resulted recently in 
numerous displaced persons and drawn active UN interventions. More recently the Office of the United Nations High Commissioner for Refugees has drawn attention to the plight of the internally displaced persons in Burundi and appealed for material and financial assistance for them.

It is extremely difficult for the international community to guarantee the safety and well-being of displaced persons fleeing war, catastrophe, massive violence and the violation of their human rights. Armed attacks on refugee camps, the abduction of politically active exiles and assaults on uprooted people making their way to a country of asylum are growing in frequency and scale. The plight of internally displaced people is often much worse than that of refugees. Generally speaking, internally displaced persons may not be individually persecuted but are fleeing from an unstable and insecure situation. In a large number of cases even where such large number of persons have crossed international borders, they have not been recognised as 'Convention refugees' since they do not face persecution as individual in their State of origin.

Simultaneous with the growing international concern for the plight of victims of man made disasters, massive violence and gross violations of basic human rights, there has been an increasing desire to avoid the overloading of the existing mechanism for the protection of the individually persecuted persons - the refugees. The customary principles of asylum too are under great strains. [footnote: Amnesty International Report, 1992]. But with the growing emphasis on respect for human rights, the international community should be more concerned with the fate of massive repression of persons wherever it occurs particularly when such repression is likely to have international repercussions through mass exodus of refugees and the concomitant burden on neighbouring States.

Consequently new legal measures to assist the displaced persons particularly in the wake of the cold war need to be taken urgently. In this context, the programmes designed to resettle displaced people in their own communities could play a vital role in reconciliation and re-establishment of peace in their country of origin. But as governments adopt more restrictive attitudes towards refugees, and as refugee settlements acquire an unanticipated permanence, work with the displaced is becoming more important and the need is increasing for establishing Safety Zones for the displaced.

Violations of human rights cannot be disregarded by the peoples of the United Nations as both the UN Charter and the Universal Declaration of Human Rights have affirmed the legitimacy of the concern of the international community for the protection of fundamental rights and freedoms. This concern is not limited to refugees alone but extends equally to all persons including internally displaced persons within their own country. Efforts to improve the situation of the displaced persons may therefore [have] to be undertaken even if that may lead to some adjustment to the concept of national 
sovereignty in the effort to conform to contemporary humanitarian needs and to effectively protect the rights guaranteed to individuals under international humanitarian conventions. One such means might be found in the concept of the establishment of Safety Zones.

It is imperative in our view that such Safety Zones should be mandated by the Security Council whose decisions are binding on all the member States of the United Nations.

\section{ROLE OF THE UNHCR IN SUCH ZONES}

A case can be made for clarifying UNHCR's role in assisting and protecting displaced people. UNHCR has normally assisted displaced people only when requested to do so by the United Nations, and permitted to do so by the authorities concerned. Such requests can be said to have hitherto been made in conformity with primacy of the importance of humanitarian assistance for the victims of natural disasters and other emergencies and the consideration that humanitarian assistance must be provided in accordance with the principle of humanity, neutrality and impartiality. The General Assembly has recognised in this regard that the magnitude and duration of many emergencies are beyond the response capacity of the affected countries. [footnote: Paragraph 4 of General Assembly Resolution 46\182 recognised that each States has the responsibility first and foremost to take care of the victims of natural disasters and other emergencies occurring on its territory. Hence, the affected States has the primary role in the initiation, organisation, coordination, and implementation of humanitarian assistance within its territory]. International cooperation to address emergency situations and to strengthen the response capacity of affected countries is thus of great importance. Such cooperation should be provided in accordance with international law and solidarity and in conformity with national law. Intergovernmental and non-governmental organisations working impartially and with strictly humanitarian motives should continue to make a significant contribution in supplementing national efforts. The starting point for UNHCR's involvement in the country of origin for the displaced persons has been said to have been affirmed in General Assembly Resolution 461182 of 19 December 1991 on Strengthening the Coordination of Humanitarian Emergency Assistance of the United Nations System. Paragraph 3 of the annex to that Resolution states:

"The Sovereignty, territorial integrity and national unity of states must be fully respected in accordance with the Charter of the United Nations. In this context, humanitarian assistance should be provided with the consent of the 
affected country and in principle on the basis of an appeal by the affected country". (Emphasis added).

As a UNHCR Working Group on International Protection rightly observed, the above cited provision argues against the UNHCR's involvement without the consent of the affected State in a Safety Zone created through 'humanitarian intervention' by one or more States against another State. The Working Group distinguished "humanitarian intervention in its classical sense from the collective action creating a Safety Zone which may have been sanctioned by the United Nations in line with its responsibilities for the maintenance of international peace and security. It clarified that as a part of the UN system, the UNHCR cannot refuse to provide humanitarian assistance in such situations, if it is requested to do so either by the General Assembly or the Security Council". [footnote: Report of the UNHCR Working Group on International Protection (Geneva, July 1992)]. The Working Group while supporting UNHCR's involvement in protecting displaced persons in their own country because of the preventive impact and the humanitarian need, emphasized that the UNHCR should, prior to initiating or accepting a request for involvement ascertain, inter alia, that:

(i) The parties concerned acquiesce to UNHCR's involvement;

(ii) The option for seeking asylum abroad remains open at all times, and that the UNHCR's involvement would not lead to or condone refoulement;

(iii) The situation calls for UNHCR'S particular expertise in protection andlor assistance and is in line with its humanitarian and non-political character;

(iv) UNHCR is granted full access and security and other conditions exist to allow it to operate; and

(v) the political support of the international community and adequate special funds are available.

The establishment of Safety Zones for the displaced persons in the country of origin should be regarded as a humanitarian measure the application of which would help curtail the creation of 'refugee population'.

The conditions in the so-called 'safe areas' in former Yugoslavia have in recent times demonstrated the difficult conditions under which people live when essential services are cut off and adequate medical 
care unavailable. People compelled to live in enclosed or delimited areas are totally dependent upon humanitarian assistance provided by external sources. The resultant camp-like feeling contributes to an overwhelming lack of normalcy in the lives of the residents of such 'protected areas'. It has therefore been suggested that donor States and international organizations should be urged to support governmental programmes of assistance to displaced people only when certain conditions are fulfilled and that such inter-government programmes should conform to the stipulations of the Fourth Geneva Convention of 1949, as this guarantees the presence and security of an international organization, prohibits the use of violence against civilians, and specifies the situations in which relocation programme can be implemented. It is however doubtful whether any conditionality to render assistance would meet the stringent requirements of the cardinal principles of humanitarian assistance viz., neutrality, impartiality and humanity. The realities of a civil strife situation which is typically marked with the absence or breakdown of any Government programme in the recognised and practical sense of the term should also be taken into account.

It has also been suggested that, donors should ensure that relief programmes for the displaced people in Safety Zones are able to function independently of the military factions. There is, however, a danger that the call for the establishment of 'Safety Zones' in such situations might provide justification for interventions by military powers. This should be avoided. Where governmental relief agencies are subject to stringent political controls, assistance should be channelled as far as possible through international organizations and non-governmental agencies acceptable to all the parties to the conflict. In this sense, the word 'humanitarian access' might be more appropriate than the word 'humanitarian intervention' as the concept of the latter term implies or connotes military intervention.

The extent to which assistance programmes for the displaced, like those for refugees, should guarantee choices and participation for the people concerned also requires to be considered at some length. Relief aid imposes its own kind of imprisonment, creating conditions of despondent dependence and hopelessness. Many displaced persons may well become like prisoners within the so called 'Safety Zone' in their own country. This psychological dimension of preventing the up swelling feeling of being in an 'open prison' needs always to be taken into account. This issue is closely related to the question of the length of time or the duration for which the Safety Zones are established. 
In December 1992 the International Committee of the Red Cross (ICRC) issued an unusual statement calling for the creation of safe haven zones in Bosnia. The ICRC is understood to have issued the call because it was convinced there was no alternative to the plan. It observed that

"as no third country seems to be ready even on a provisional basis to grant asylum to one hundred thousand Bosnian refugees (the group under immediate threat in the north of Bosnia-Herzegovina) an original concept must be devised to create protected zones . . . which are equal to the particular requirements and the sheer scale of the problem". Ufootnote: Bill Frelick, 'Preventing Refugee Flows: Protection or Peril?' in: World Refugee Survey 1993].

This statement refers to safe havens in the country of origin not as the preferred way to protect would-be refugees, but rather as a last resort to save the individuals concerned since denial of asylum by outside countries had closed the option of asylum. The ICRC faced with the stark reality of prevention of refugee outflow by other governments turned to 'safe haven' idea as an act of desperation to protect the trapped after international refugee regime had failed. The conditions which the ICRC listed and which would have to be met to establish such safe haven zones included inter alia the consent of the parties concerned to the concept and location of such zones and duly mandated international troops to assure security of such protected zones. The ICRC's safe haven proposals were based on the $a$ priori assumption that asylum outside Bosnia is not an option. However, it should be recalled that in her Note on International Protection, the United Nations High Commissioner for Refugees emphasized that "prevention is not . . . a substitute for asylum." [footnote: See Note on International Protection, submitted by the High Commissioner, Executive Committee of the High Commissioner's Programme, Forty-third session, August 25, 1992].

Consequently, in our view any proposal for the establishment of a safe haven zone should not preclude the options of seeking asylum outside the country of origin. Thus, admission to or residence in the zone should not affect the right to seek asylum, nor should it restrict the right to freedom of movement of the person in and out of the Safety Zone. 'Operation provide comfort', launched in northern Iraq following upon the adoption of Security Council Resolution 688 of April 5, 1991, was not an effort to address the root causes of the refugee flow so that potential refugees would feel secure enough to choose not to flee. On the contrary they had no choice since asylum in neighbouring countries was denied. While such zones or areas ought to provide sufficient security to convince displaced persons that they can be adequately protected without crossing an international border, they should not be used as a pretext for barring the movement of those who still feel endangered to seek refuge outside their countries. 
A major consideration in the creation of a Safety Zone is its effectiveness in actually providing safety to those in need. The UNHCR takes the view that guarantees for safety need to be explicitly and effectively underwritten as clearly as possible. They will depend on the actual circumstances, including the degree and nature of the threat as well as the methods used to establish the Safety Zone. If a Safety Zone is created with the consent of the parties, their assurances may provide a basis for safety. If it results from multilateral action, international supervision by a UN peace keeping force may be an option. The presence of international observers or monitoring by organisations, including UNHCR may also be important additional methods. But experience has shown that such operations are cumbersome and very expensive.

While the humanitarian law stipulations envisage the creation of various types of areas under special protection, they do not provide for the physical protection of such areas. It may be stated in this regard that Article 5 of The Draft Agreement Relating to Hospital and Safety Zones and Localities, attached as Annex I to the Fourth Geneva Convention, stipulates inter alia that hospital and safety zones "shall in no case be defended by military means". This restriction is also extended to localities under Article 13 of the Draft Agreement. Yet, where parties do not respect an area under special protection, protection cannot be assured to the persons therein without the use of military means. The safety of the security zone in Iraq as opposed to the lack of security in the protected areas and safe areas in the former Yugoslavia highlight this aspect.

Furthermore, a multitude of questions arise in connection with the necessity to ensure the safety of those in the area under special protection. What type of legal framework would be effective in guaranteeing the security of persons in the area - municipal law and structures, regional or universal regimes? While applicable human rights and humanitarian law obligations would, perhaps, continue to apply, refugee law as such would be inapplicable since such persons remain in their country of origin. Who would be most effective in enforcing the rules governing the area under special protection including those prohibiting violation of the security of the area? Also, how will the safety of those in the area be ensured - by the police or paramilitary forces of the State or by an international peacekeeping force? How will entry and exit to the protected areas be controlled and by whom? How and by whom would the demilitarization of the area be effected and ensured? Would the prospect of creating areas under special protection induce parties to try to annex such areas before their protection is established, thus putting at risk the very people the areas under special protection are supposed to protect?

Indirectly related to ensuring the safety of persons in the area, but essential to the smooth functioning of the area, are questions about who will 
administer the area and whether the United Nations agencies will play a monitoring role or an active participatory role in the area by carrying out functions normally performed by the government.

Another factor to be borne in mind is the length of time for which a Safety Zone need be created. How temporary a measure of protection turns out to be would depend on the success of political initiatives to resolve the underlying conflict. The dangers of failure to reach a political settlement are serious. The cost of maintaining a Safety Zone for a long period and the number of persons it might attract could be astronomical and may make it an unworkable proposition. These concerns underscore the importance of political initiatives for a solution in parallel to the establishment of a Zone. In the absence of a political settlement a protracted camp-like situation might result in demands by persons in the zone for transfer abroad. Yet again, the existence of an area under special protection could well strengthen the political initiative and intention to find a comprehensive solution to the conflict. The AALCC may also wish to consider whether the creation of areas under special protection for an indefinite period of time would not also significantly increase the number of persons dependent on international assistance for a protracted period of time.

The final consideration relates to the presence and participation of other organizations, governmental and non-governmental, in the Safety Zone. The value of inter-agency co-operation would be enhanced in the politically delicate situation of a Safety Zone. From an assistance point of view, the need for inter-agency cooperation to bridge the gap between relief and rehabilitation is well-recognised. The protection, as much as assistance of the displaced should be seen as a cooperative effort between international intergovernmental organisations and states as well as nongovernmental organizations, particularly in filling the gaps between UNHCR's protection responsibilities and the overall needs of the displaced population. It may also be relevant in the context of the mandate entrusted to UNHCR in its operations, since even though UNHCR's protection objectives may have been met, this does not mean that the human rights of the individuals are fully protected. It is important therefore to keep in mind the specific mandate of ICRC for the protection of civilians, as well as the human rights protection and promotion responsibilities of other UN operations. In this respect, the various initiatives which have been launched within and outside the UN to focus greater attention on the plight of the displaced persons - including the internally displaced should be kept in mind. 
This topic needs further serious study with a more careful evaluation of the situation and practice in recent times in such areas as in northern Iraq, Sri Lanka, Yugoslavia, Somalia among other. The AALCC should give consideration to the directions which the future work of the Secretariat should take. Not only are we dealing with a novel concept but in the absence of a consistent and uniform terminology, the fine distinction between the emerging principles of humanitarian law and the customary principles of human rights and refugee law place the concept in a dark grey area where the two aforementioned branches of law overlap. The usage of a plethora of terms such diverse as 'Safety Zones', 'Open Relief Centres', 'Security Zones', 'Safe Haven Zones', 'Safe Corridor', and 'Safety Corridors', not to mention 'humanitarian access', can scarcely be said to be conducive to the progressive development or codification of law where several customary and codified principles of International Law interact, coincide and at times even appear to be mutually exclusive. This is particularly true of the principles of State Sovereignty and non interference in the domestic affairs of the State. The Committee should give consideration to these and other matters referred to above in determining the future work of the Secretariat in this regard."

22. Introducing the item, the Deputy Secretary-General said that the future work of the Secretariat concerning a model law would depend on Member States' views on the meaning and scope of some key terms that would be used in the legislation contemplated as well as the extent of the rights and duties to be conferred upon persons protected under it. On the subject of safety zones, he emphasized the difficulty of dealing with issues which arose within an area of interaction between the emerging principles of humanitarian law on the one hand, and principles of State sovereignty and non-interference in the domestic affairs of States, on the other. He sought the guidance of the Committee on both aspects of the item before it.

23. The delegate of Iran noted the importance of refugee problems, particularly in Asia and Africa. He observed that Iran had been host to some 5 million refugees and, as a Party to the 1951 Convention on the Status of Refugees and its 1967 Protocol, had taken steps to provide facilities for refugees within its territory. Although international organizations had expressed appreciation for Iran's efforts, international aid for refugees in Iran had been insignificant when compared with that given to other countries which had taken in smaller numbers of refugees. In his view, measures and policies of a State resulting in displacement of its nationals and their taking refuge in other countries, amounted to a mass expulsion of persons for which the country of origin remained responsible. He emphasized that such displacement could not be used as justification for denying the nationality of the persons 
displaced; that a receiving State had the right to facilitate repatriation of such persons whenever it ascertained that the situation in their country of origin had become normal; and that refugees were themselves bound to act in accordance with the laws of the receiving State.

\section{The Representative of the United Nations High Commissioner for Refugees} said that every State needed to adopt legislation that would enable it to manage and regulate humanitarian assistance to be rendered to refugees and displaced persons. He observed that a legal regime could at once protect the interests of asylum seekers, and ensure the protection and preservation of the sovereignty of a State, as well as its national interests. He proposed that the AALCC should second a member of its staff to the Secretariat of the UN High Commissioner for Refugees for a mutually agreed period, to draft model legislation on refugees. The proposed legislation, he said, could be modular, with alternative provisions, and could be submitted to Member States for their observations, additions and amendments. The draft could then be considered and perhaps approved by the Committee at its next session. Thereafter member States which desired to do so, could enact legislation receiving, if necessary, technical assistance from the office of UNHCR.

25. The delegates of Uganda and Kenya welcomed the offer by UNHCR of technical assistance in the drafting of a model law. The delegate of Kenya, recalling that his country had been host to a large number of refugees over a period of some 20 years, observed that the influx of such numbers had an adverse effect on the economy, sometimes (as when refugees brought arms with them) created a climate of insecurity which inhibited foreign investment, and had even led to environmental hazards through the cutting down of trees on a large scale for fuel. He noted that although Kenya had to endure such consequences, it had received only limited assistance from the international community.

26. The delegate of India said that the impact of the influx of refugees varied from country to country and from continent to continent. He emphasized that there were many aspects of the problem which needed further careful study and deliberation before the drafting of a model law on the subject could be embarked upon, such as definitions of terms and scope of the proposed legislation. He did not favour introducing into such legislation ideas which had not been accepted voluntarily following detailed discussion, and could not agree to seeking technical assistance in the matter of drafting a law at this stage. He would not, however, be opposed to seeking technical assistance in the drafting of modular legislation at an appropriate time, provided that it was 
understood that the existence of the proposed model legislation would not commit or bind any Member State of the Committee, and that adoption of any such legislation would be voluntary. The delegates of Egypt and Turkey expressed general agreement with the views of the delegate of India.

27. The Representative of UNHCR pointed out that Member States of the Committee would remain at liberty to consider the substantive and political questions related to the acceptance or enactment of the proposed legislation. The Secretary-General agreed that preparation of model legislation by the AALCC Secretariat with the collaboration of UNHCR would not make it mandatory for any Member State of the Committee to enact such legislation. In his view, such model legislation could be of use to many Members in developing their own laws to assist refugees.

\section{Decision}

28. In the decision adopted (Report, pages 227-8) following discussion of the item (Report, pages 136-145 and 155-7) the Committee, inter alia:

“...

1. Appeals to Member States to take all measures to eradicate from their countries the causes and conditions resulting in their nationals being forced to leave their countries and becoming refugees;

2. Urges the Member States who have not already done so to ratify or accede to the Convention on the Status of Refugees, 1951 and the 1967 Protocol thereto;

3. Takes note of the general outline of the programme of work proposed by the Secretariat on the model legislation which is still to be considered by the Committee;

4. Decides to continue with the task of the preparation of a model legislation in close co-operation with UNHCR and OAU in light of the codified principles of international law and the practice of States in the region;

5. Expresses appreciation to the UNHCR for the offer to assist the AALCC to draft the model legislation;

6. Decides in the context of paragraph 4 above to second a professional staff officer of the Secretariat to the UNHCR, for a specified period to be mutually agreed, to draft the detailed modular draft legislation; 
7. Recommends that such draft legislation be transmitted by the Secretariat to all Member States, prior to the Thirty-fourth Session, for their consideration, amendments, additions on substractions;

8. Recommends further that such duly amended draft legislation be considered at the Thrity Fourth Session of the Committee for its possible adoption;

9. Directs the Secretariat to include the item 'Status and Treatment of Refugees' on the agenda of the Thirty-fourth Session of the committee; and

10. Directs the Secretariat to study further the concept of Safety Zones and to analyse the role played by the United Nations and UNHCR, in particular in the recent past, in that context."

\subsection{Law of international rivers}

29. The Committee had before it a document entitled "Law of international rivers: normative approaches to the sustainability of freshwater resources" (Doc. No. AALCC/ XXXIII/TOKYO/94/5) prepared by the Secretariat, which examined some legal obstacles to the establishment of a complete international regulatory mechanism for sustaining freshwater resources and their flows. The study was based on principles and draft texts adopted by the International Law Commission in connection with its work on the topic "Non-navigational uses of international watercourses", and drew heavily upon the work of the United Nations Conference on Environment and Development, in particular Chapter 18 of Agenda 21.

30. Referred to the Committee in 1966 by Iraq (concerned with defining the term 'international river', and clarifying rules relating to the utilization of the waters of such rivers for purposes not connected with navigation) and by Pakistan (concerned with clarifying the rights of lower riparian states), this item serves (1) to focus discussion on areas of importance to Member States that are not likely to be covered by the International Law Commission, as well as (2) to assist Member States to monitor and formulate views concerning progress of the Commission's work. India has regularly expressed doubts regarding the usefulness of proceeding with consideration of the item due to the diversity and complexity of the factors involved.

31. The delegate of Turkey said that, while he welcomed draft article 5 of the International Law Commission which concerned the "utilization of an international watercourse in an equitable and reasonable manner", he could not 
accept such a concept in the utilization of groundwater resources. He recalled that his delegation had pointed out during the Committee's Islamabad Session (2 AsYIL 204) that inclusion of confined groundwater resources could add to the complexity of the subject, but said he had not (as had been erroneously reported) proposed such a course. His delegation believed that since diverse factors characterized river basins in various parts of the world, the item under discussion was not amenable to further examination by the Committee. He said that, in any event, the title of the item should be changed from 'Law of International Rivers', which wrongly implied the existence of an accepted body of law on the subject, to "Study on the non-navigational utilization of international watercourses".

32. The delegate of India said that the essentially bilateral dimensions inherent in the topic were such that multilateral efforts to formulate rules merely resulted in work of a high level of generality and abstraction. Accordingly, he suggested that the Committee reach no final conclusion, and that the item be withdrawn from its active agenda.

\section{Decision}

33. Discussion of this item (Report, pages 96-8) was followed by adoption of an essentially procedural decision (Report, p. 229).

\subsection{Law of the sea}

34. The Committee had before it a Secretariat document entitled The law of the sea: the work of the Prepcom and the UN Secretary-General's informal consultations (1993) (Doc. No. AALCC/XXXIII/TOKYO/94/6) which summarized progress made at the Eleventh Session of the Preparatory Commission for the International Seabed Authority and for the International Tribunal for the Law of the Sea (pages 1-14), as well as progress made at the UN Secretary-General's informal consultations aimed at reaching agreement on practical solutions for the difficulties relating to part XI of the UN Convention on the Law of the Sea (deep sea-bed mining) which the industrialized countries indicated had arisen in changed circumstances following negotiation and signature of the Convention (pages 14-57). The ultimate objective of the consultations was to secure broad agreement concerning implementation of the Convention so that, deposit of the 60th ratification (required to enable the Convention to enter into force) being imminent, the participation of all countries developing and industrialized, those which had 
signed, but not ratified the Convention, and those which had not yet signed it - would be facilitated.

35. Reporting on the UN Secretary-General's consultations the Secretariat summarizes and compares the contents of two documents: the 'Boat Paper', which had been the basis of the informal consultations, and of which the AALCC Secretariat observes that it was ". . . an anonymous paper, purported to have been prepared by representatives of several developed and developing States . . . however, it is clear that the majority of the developing countries could not have been parties to it and were neither consulted nor support its content"; and a 'Non-Paper' said to have been prepared by "delegations primarily from the Group of 77". The 'Boat Paper' (so-called because of the sea-bed mining vessel depicted on its cover) discussed proposals for 'implementing' part XI of the Convention while modifying obligations provided for under it, as well as 'procedural approaches' to accomplishing that objective. To the Boat Paper was attached a draft resolution for adoption by the UN General Assembly, together with an "Agreement relating to the Implementation of Part XI of the 1982 United Nations Convention on the Law of the Sea" which would be subject to signature and ratification (reproduced at pages 63-91 of the document). The 'Non-Paper' entitled "Agreement on the Implementation of Part XI and Annexes III and IV of the United Nations Convention on the Law of the Sea", contemplated (a) extention of the mandate of the Preparatory Commission for an "interim period from the coming into force of the Convention to the time when commercial seabed mining becomes feasible"; (b) authorizing the Preparatory Commission "to exercise all the initial functions of the Authority and the Enterprise in accordance with the Convention, in an evolutionary manner, during this interim period"; (c) the convening of a "review conference at the time when commercial sea-bed mining is about to begin"; and (d) adoption of the text of an Agreement annexed to the draft resolution giving effect to the foregoing, which would be subject to signature and ratification (reproduced at pages 57-62 of the document). In its 'Conclusion' the Secretariat document observes,

"In the circumstances, as these consultations progress, it is necessary that more attention should be given to the 'Non-Paper' which offers practical solutions for the interim period".

36. The delegate of Sri Lanka said that the developing countries should focus on immediately realizable benefits from marine areas under national jurisdiction, since prospects for deep-sea mining operations appeared to be receding. While emphasizing the importance of preserving the universality of 
the Convention, he said that it was only through regional co-operation, and with the support of the industrialized countries and international organizations that the developing countries could make practical gains. It was for that reason that Sri Lanka had, in 1981, proposed the establishment of the Organization for Indian Ocean Marine Affairs Co-operation (IOMAC).

37. The delegate of Indonesia said that while many provisions of the Convention were the result of the codification of rules of customary law, others like those concerning the exclusive economic zone, the archipelagic state, protection and preservation of the marine environment, transit passage through straits used for international navigation, sea-bed mining and mandatory dispute settlement established new legal regimes. He declared that it was imperative that Member States of AALCC utilize the period before 16 November 1994 (on which date the Convention would enter into force) to secure universal adherence to the Convention, so as to consolidate and further strengthen those provisions, observing, however, that the legal regime of the exclusive economic zone had become part of customary international law as evidenced by state practice.

38. The delegate of Japan recalled that his country, as a maritime State, had played an active rôle throughout negotiation of the Convention, as well as at the Secretary-General's consultations. The Convention deserved positive appraisal despite shortcomings related to part XI, and would serve the longterm interests of maritime states through providing an integrated legal basis for use of the seas by the international community, and by putting an end to disorder resulting from unilateral extentions of jurisdiction by coastal states. In his view, the successful conclusion of the Secretary-General's informal consultations was essential in order to safeguard agreed aspects of part XI, to ensure the establishment of a universal legal regime for the oceans, and to prevent erosion of that regime or selective adoption by states of parts of it which they found beneficial to themselves. To achieve that objective, it was necessary to accommodate the views of the developed countries as well as the new political and economic conditions that had emerged after adoption of the Convention. With reference to the work of the Preparatory Commission, he said that since the adoption of the Understanding on the Fulfilment of Obligations by Registered Pioneer Investors, Japan's Deep Ocean Resources Development (DORD) had faithfully implemented their obligations, including establishment of a training programme, which had been approved by the Commission. Under it, three trainees from Thailand, Iran and the Republic of Korea were since 1993 taking 10-month courses in their respective fields viz. geology, geophysics and electronic engineering, under the auspices of DORD 
and the Geological Survey of Japan, within the framework of the Japan International Cooperation Agency (JICA). These trainees were expected to play a central role in the future Enterprise.

39. The delegate of Kenya said that the provisions of the Convention, particularly part XI, represented a compromise between developed and developing countries. While supporting the UN Secretary-General's consultations, he observed that that forum had no mandate to discuss amending the Convention, and that, prior to the entry into force of the Convention, only the Preparatory Commission had such a mandate. He expressed concern regarding the issue of decision-making once the Convention entered into force, noting that it was unclear how the industrialized countries could participate in the work of the International Sea-bed Authority if they did not become parties to the Convention. Recognizing that regional cooperation promoted the interests of the developing countries, he said that training programmes under the auspices of IOMAC had benefitted many countries in the Indian Ocean region.

40. Welcoming deposit of the sixtieth instrument of ratification of the Convention, and its entry into force on 16 November 1994, the delegate of China expressed the hope that the largest possible number of countries would become parties to it. He observed that the effectiveness of the Convention would be damaged if the industrialized countries were to stand outside it. Welcoming the informal consultations convened by the UN Secretary-General on deep seabed mining issues, he called upon all States to use the period before the Convention's entry into force to find satisfactory solutions so as to allow the Convention to be accepted as widely as possible. He said that there was clear evidence that the Preparatory Commission had successfully implemented Resolution II of the Third UN Conference on the Law of the Sea, and expressed the hope that the Commission at its forthcoming session would make practical arrangements for the entry into force of the Convention.

41. The delegate of the Republic of Korea, while welcoming deposit of the sixtieth instrument of ratification by Guyana and the prospect of the Convention's entry into force in November 1994, observed that the universality of the Convention remained to be secured, and expressed the hope that the UN Secretary-General's consultations would bring about that result. He announced that his Govemment had applied to the Preparatory Commission for registration as a pioneer investor and for the allocation of a pioneer area in accordance with Resolution II of the Third UN Conference on the Law of the Sea. 
42. The delegate of India expressed the hope that the UN Secretary-General's informal consultations would result in the emergence of a consensus which could be introduced into the Convention on the Law of the Sea through its existing machinery. That, in his opinion, would ensure the due and effective rôle of every State in the establishment of the ocean regime. He expressed the view that states which made substantial investments in the oceans would ensure the protection of the principle of the common heritage of mankind.

\section{Decision}

43. In the decision (Report, pages 231-233) which followed discussion of the item (Report, pages 111-125) the Committee, ${ }^{1}$ inter alia,

“. . .

2. Notes with great satisfaction that the United Nations Convention on the Law of the Sea having been ratified by the requisite sixty states shall enter into force on 16 November 1994;

3. Urges the Member States who have not already done so, to consider ratifying the Convention on the Law of the Sea;

1 The delegate of Japan made the following observation at the adoption of the decision: "Japan believes it essential to ensure the universal application of the Convention. It is encouraging to note that an increasing number of countries recognise the urgent need for arriving at a most widely acceptable agreement through the negotiations at the Secretary General's Informal Consultations prior to the entry into force of the Convention. Japan also hopes that the consultations would lead to a conclusion which would fully reflect the legitimate interests of international community as a whole, including both of the developing and of the developed countries".

The delegate of Turkey made the following reservation with respect to the decision:

"Turkey supported the international efforts directed to establish a regime of the Law of the Sea which has to be based on the principle of equity and which can be accepted by all States. However, the Convention on the Law of the Sea does not contain the adequate provisions for special geographical zones and situations and, as a consequence, can not succeed to establish a satisfactory balance between the conflicting interests. Furthermore, the Convention contained no provision for reservation on specific clauses. These are the main reasons to prevent Turkey from approving the Convention on the Law of the Sea. Although the Convention is about to enter into force, it is still far from getting universal acceptance. As the distinguished delegate of Sri Lanka mentioned in his statement, lack of equity as between the conflicting interests is the source of the informal negotiation conducted with the help of the Secretary-General of the UN.

We do not want to create an obstacle to the decision to be taken by the Committee but, my delegation would like to reserve its position on the issue and express clearly that its silence can not be interpreted as an approval to the resolution which is supposed to be adopted by consensus." 
4. Urges the full and effective participation of the Member States in the Informal Consultations convened by the Secretary-General of the United Nations so as to ensure and safeguard the legitimate interests of the developing countries;

5. Reminds Member States to give timely consideration to the need for adopting a common policy and strategy for the Interim Period before the commercial exploitation of the deep seabed minerals becomes feasible;

6. Urges Member States to cooperate in regional initiatives for the securing of practical benefits of the new ocean regime;

7. Directs the Secretariat to continue to cooperate with the international organization and with such international organizations competent in the fields of ocean and marine affairs and to consider assisting Member States in the formulation and adoption of municipal legislation for the exploration and exploitation of the natural resources of the Exclusive Economic Zone;

\section{MATTERS OF COMMON CONCERN HAVING LEGAL IMPLICATIONS}

\subsection{The United Nations Conference on Environment and Development: follow-up}

44. The Committee had before it the following documents prepared by the Secretariat:

"United Nations Conference on Environment and Development: follow-up" (Doc. No. AALCC/XXXIII/TOKYO/94/7); a supplement thereto with the same title (Doc. No. AALCC/XXXIII/TOKYO/94/7a), and "Report on AALCC's Legal Adviser's Meeting, New York, 27 October 1993” (Doc. No. AALCC/XXXIII/TOKYO/94/10).

45. Doc. No. TOKYO/94/7, describing institutional arrangements for giving effect to decisions taken at UNCED, notes that within one year of the Conference, the UN General Assembly, by resolution 47/191 adopted on 22 December 1992, has established the Commission on Sustainable Development, to consist of 53 representatives of States elected by the Economic and Social Council for 3 year terms and to meet once a year; and a High Level Advisory Board to consist of eminent experts on environmental matters, all in 
accordance with recommendations contained in chapter 38 of Agenda 21. The document also notes adoption by the Commission of a "thematic multi-year programme of work", the establishment of an Inter-Agency Committee on Sustainable Development to promote co-ordination of the activities of international organizations, the creation of a new Department for Policy Coordination and Sustainable Development within the Secretariat (headed by Under-Secretary-General Nitin Desai), and the establishment by some 70 countries of national commissions to implement Agenda 21. While conceding that it might be too early to attempt a comprehensive assessment of overall progress, the document observes (pages 7-8):

"While the process of establishment of institutional arrangements as envisaged
at the Rio Conference has been completed satisfactorily, there appears to be
little progress on the two key issues, namely the financial commitments
involving new and additional resources and the transfer of environmentally
sound technology to the developing countries. It will be recalled that the
successful adoption of Agenda 21 at the Rio Summit added a new dimension
to the concept of partnership among the developed and the developing
countries. The need of the hour is to sustain and strengthen this concept."

46. Doc. No. TOKYO/94/7 then focusses on work done on the drafting of a convention to combat desertification in those countries experiencing serious drought and/or desertification, particularly in Africa. Having described the work carried out in 1993 by the Inter-governmental Negotiating Committee on Desertification (INC-D) established pursuant to UN General Assembly resolution 47/188, the AALCC Secretariat offers general comments, as well as its own "tentative draft text of a Convention on Desertification and Mitigation of Drought" (pages 11-59), emphasizing that the views expressed therein "do not necessarily reflect the position of any of the Member States of the AALCC":

“. . .

\section{GENERAL COMMENTS}

The Geneva Session of the INC-D was a step forward toward the goal of completion of the elaboration of a convention by June 1994. The compilation prepared by the INC-D Secretariat with the assistance of the International Panel of Experts helped to focus the discussions on a set of proposals on the relevant issues.

It appears that there will be no disagreement on the format of the Convention which will essentially follow the pattern established by the 
Convention on Climate Change and Biodiversity. The unanimity reached at the opening of the INC-D Meeting in Geneva on the allocation of work to the two Working Groups was a good omen at the commencement of the negotiating work in Geneva. The two Working Groups during the first week of the Session made a remarkable progress in the first round of discussions on the basis of the compilation made by the Secretariat (Doc. A/AC 241/12). Regrettably, during the later part of the second week, the deliberations got derailed over the semantics.

It is, however, encouraging to note that there is wide consensus on several provisions of the Convention. The divergent views in respect of Preamble, Definitions, Principles, Objectives, Research and Development, Capacity Building, Technology Transfer and Co-operation, Institutional and Procedural Arrangements and Final Clauses will narrow down as the negotiations reach the concluding phase.

There are only three key issues which could keep the INC-D negotiations on tenterhooks. These issues include: the nature and type of commitments, the financial resources and mechanism, and the nature and time table for conclusion of regional instruments. At the conclusion of the Nairobi Session it was hoped that especially the issues concerning regional instruments will not pose problems at the Geneva Session. Regrettably, this was not to be.

It is interesting to note that many of the developed countries purport to advocate that this should be a 'strong' convention. However, if the views expressed at the Geneva Session on crucial issues such as ccommitments and the financial mechanisms are any indication, the Convention, when it emerges in the final form, would perhaps be among the 'weakest' on this field of environment and development. The differences of opinion on a single word 'globalization' substantiates this observation. For the climate change issues, the developed countries had vital stakes and therefore they were prepared to cajole and to go to some length to seek support and participation of the developing countries in that process. It may be too harsh to express the opinion that in some quarters, it is felt that 'desertification convention' is a 'charitable convention'. Such a view would be a travesty of the whole international co-operation system currently in vogue. The semantic differences over the character of the issue and whether it is 'global' or not should not be the yardstick to judge the importance of the international convention to combat desertification.

It has been further suggested that the convention should be 'realistic' and should not deal with issues which are not relevant in the context of the desertification convention. Nobody would dispute that point. However, the word 'realistic' has to be interpreted in the context of overall approach, both by the developed and developing countries. It has been recognised that 'desertification' and 'drought' are two distinct issues and accordingly different types of commitments should be elaborated to deal with them. Drought has been defined as "a sustained period of water deficit in particular areas, 
perhaps lasting a few months or many years". Does it mean that one has to wait for many years to identify any particular situation whether it is 'drought' or 'desertification' and provide any assistance accordingly? In the context of desertification, it has been further suggested that the proposed Convention should deal with 'preventing' further desertification and not with the problems of 'reclamation' of degraded land. If the objective is to adopt an 'integrated approach' such different categories of situations, involving different types of comitments does not seem to hold logic. There cannot be a dividing line separating these issues. As and when the Convention comes into force, the Conference of Parties (COP), the highest body designated to oversee the implementation of the Convention, should consider the specific situation in the light of scientific information available and take a decision as to what type of technical and financial assistance would be necessary to deal with that type of situation. If the Convention is to be realistic, it must be flexible in its approach on this issue. Instead of arguing for drawing fine distinctions, it should be left to the Conference of Parties to determine the specificity of each situation and act accordingly.

It has been suggested that the Convention should strictly deal with the issues which are relevant in the context of desertification issues. The very mention of 'biodiversity' or climatic issues have not been recognised as relevant, as they are being dealt within other international Conventions. Similarly, since sensitive issues such as mitigation of debt or removing distortions in international trade belong to other international forums, it has been argued that they should not cast their shadows in the negotiations on a desertification convention. No doubt, these issues are not directly related to this exercise, but there is no doubt they are relevant and could be mentioned albeit in a very general manner, perhaps either in the preamble or in the article relating to 'Principles'. Nobody is seeking solution of the debt problem in the context of desertification but the debt burden of developing countries is a reality which is hampering their development process and unless it is seen in a broader perspective no meaningful achievement could be made in any front including combating disertification and drought.

In the context of relevance of issues, a couple of observations may further be made. In some quarters it is felt that the Convention should not fail to refer to 'good governance' and the virtue of a democratic form of government. Some veiled charges were also made in identifying the reasons why past efforts and financial assistance provided to developing countries, could not yield the desired result. It is unfortunate but true that democracy while crucial is not the panacea for all the ills of today's world. There are examples where supposedly democratic governments have systematically exploited their own people and become involved in all types of corruption and other instances when authoritative regimes have done best for the welfare of their people and led to phenomenal development. In the context of desertification, it is not the type of government which matters. Each situation should be judged by 
performance and the way that commitments at the national level have been implemented by the Governments. The convention should not attempt to impose a 'charter for good governance' and dictate the national budgetary process and other matters lying in the national domain. Respect for sovereignty and freedom for independent action should be one of the elements in granting international assistance to deal with such problems as desertification which are essentially within the national jurisdiction of States. Such an approach only would make the Convention realistic.

Another set of provisions which would be the yardstick to measure the success of the Convention are the financial commitments and the related mechanism to implement the Convention. Perhaps Geneva during the INC-D second session did not provide the right atmosphere to discuss seriously the financial commitments to ameliorate the conditions of millions who are struggling for survival from the menace of desertification far away. The views expressed during consideration of this item in Working Group I do not appear to be encouraging. There is so far little indication from many of the developed countries of their desire to reach the target of 0.7 percent of their GNP in response to the fervent appeal made just a year ago during the Rio Summit. There is little inclination to support the establishment of a separate and special fund within the context of the desertification Convention. On the contrary, there is strong opposition to open a fifth window at the Global Environment Facility (GEF) specifically for desertification issues. It has been suggested that 'desertification' may attract GEF funds in specific situations which may fall under the four programme areas covered under the existing scheme. Although, the discussions on restructuring of GEF are still going on and any clear view on this issue would emerge only after GEF's December 1993 session, there is not much hope of breaking any new ground.

Against this background, it would not be surprising if the fate of discussion on crucial issue of 'new and additional financial resources' will hang in the balance until the last moments of the negotiating process. The negotiating history of the Climate Convention provides a precedent in this regard. The Convention on desertification, however, must address this issue in a pragmatic or innovative manner which will pave the way for any realistic Convention.

Another difficult issue, which remained unresolved at the INC-D first session in Nairobi, and continued to haunt the deliberations in Geneva, is the conclusion of regional instruments. UN General Assembly Resolution 47/188 of 22 December 1992 mandated the INC-D to elaborate an international convention to combat desertification in those countries experiencing serious drought and/or desertification, particularly in Africa, with a view to finalising such a Convention by June 1994 . The absence of any clear guidelines and the determined time-frame have resulted in a difficult situation and a variety of interpretations. 
One view is that the resolution only refers to the conclusion of an international Convention by June 1994. It does not specify elaboration of any regional instrument within this time. The other view, stressed by many delegations, particularly the African States, is that the text of a regional instrument for Africa must be completed within the stipulated time along with the Convention. The third view, advocated by the States from the Asian, Latin American and the Northern Mediteranean regions, seeks simultaneous elaboration of similar regional instruments for their respective regions.

It is our considered view that it may not be feasible to complete the entire work of the elaboration of the Convention together with all the regional instruments by June 1994. The Chairman of the INC-D initially pult forward a proposal which proposed to seek from the Forty-Eighth Session of the General Assembly an extension of the mandate of the INC-D until August 1995. The obvious implications would have been additional financial commitments by the United Nations and the countries which are supporting the INC-D negotiating process by making voluntary contributions to the Special Fund and the Trust Fund established by the General Assembly (Res. 47/188, Paragraph 13, 14 and 15).

Subsequently, the Chairman submitted another draft on 21 September 1993. In this revised paper, the extension time sought is until January 1995. The marked reluctance of some countries who are contributing to these funds and the continuing financial squeeze of the United Nations may pose some difficulties. However, it is presumed that the Chairman through his skill and pursuasive manner will succeed in his mission when the General Assembly takes up the item on report of the INC-D for consideration. At this juncture, one can only speculate whether even with this extension it would be feasible to complete the entire process.

Apart from the time-frame, the nature of regional instruments raise several difficult legal issues. Two kinds of legal instruments could be elaborated, protocols or annexes. It appears that the general view at the Geneva Session is in favour of annexes. Adoption and integration of protocols with the main Convention is a complex process. However, a similar complexity may arise in the context of annexes. The protocol and annex are integral parts of the Convention. Generally, protocols deal with more substantive legal matters and annexes are concerned with the technical, administrative and procedural matters. In the event, the INC-D contemplates elaborating instruments as annexed. Presumably, there will be at least four annexes covering four different regions, i.e. Africa, Latin America including Carribean, Asia including the Central Asian region and Northern Mediterranean respectively.

It is hoped that the INC-D will complete the elaboration of the Convention by June 1994 and possibly the text of the annex for Africa. The Convention, together with the African annex should be adopted by the General Assembly at its forty-ninth Session and thereafter be open for signature by Member 
States of the United Nations. If other annexes are concluded thereafter, how will they be integrated with the Convention? Would a state which signs the Convention at the first instance, be expected to sign the subsequent annexes? If for any reason, it chooses not to do so, what will be the legal effect of subsequent annexes vis-a-vis that State? To stretch this question further, would any State have the option to pick and choose one of the annexes and declare itself not to be bound by other subsequent annexes if it chose not to ratify/accede to them. These are just a few legal issues which would need to be considered in this context.

The AALCC Secretariat is of the view that a convention accommodating the situations in different regions and specifying particular measures to deal with situations in Africa would have been the ideal approach. However, this may not be acceptable to African countries as it would not fully meet their aspirations. The alternative is to elaborate a general convention together with separate regional instruments for different regions. In our view these regional instruments should not seek to establish additional commitments beyond those envisaged in the convention for the parties which do not face any desertification and drought problem. Other Contracting Parties, which do face such problems, may commit themselves to initiate and implement such measures as would be necessary in the context of their respective regions. Since the idea of the regional instrument as an 'annex' is gaining ground, it would be desirable to identify the common elements and elaborate administrative and technical details corresponding to the specificity of each region. As for the time-frame, since all the annexes would be identical in terms of their legal effects, it would not matter which is elaborated first. The IMO has evolved a very practical system of 'tacit acceptance', of annexes. Such a provision could also be considered in the context of this Convention. This would do away with the problem of integration of annexes with the main Convention.

Another interesting example which may be relevant in this context is the 'Implementation Agreement' relating to the implementation of Part XI and related provisions of the United Nations Convention on the Law of the Sea of 1982, currently under discussion in the Informal Negotiations initiated by the UN Secretary General. The initiative of the UN Secretary General to hold consultations on the outstanding issues on the Law of the Sea Convention, is intended to lead to an Implementation Agreement which would facilitate universal participation in the Convention. Article 2(2) of the Implementation Agreement now under discussion envisages that the provisions of Part XI and the Implemementation Agreement would be read and interpreted together as one single account. Under Article 3, this Agreement would be ". . . open for accession by those States and other entities referred to in Article 305 of the Convention which have ratified or acceded to the Convention or which are simultaneously ratifying or acceding to the Convontion and this Agreement". Further, Article 4 provides for a simplified procedure. A State or entity which 
is a Party to the Law of the Sea Convention prior to the adoption of the Implementation Agreement, "[. . .] would be considered to be a party to this Agreement unless it notifies the Depository within 12 months of the adoption of the Implementation Agreement that it would not have recourse to the simplified procedure as set out in Article 4."

The AALCC Secretariat is of the view that a combination of "tacit acceptance' and 'simplified procedure' could provide a solution to the difficulties which might arise in the context of the conclusion and implementation of regional annexes to be adopted after the conclusion of the Convention. While 'tacit acceptance' could promote expeditious entry into force of the regional annexes, the simplified procedure might help in sorting out the legal problems raised in relation to the implementation of annexes.

Lastly, the Fourth ACP-EEC Convention, popularly known as Lome IV Convention, signed in Lome on 15 December 1989 will be a very useful precedent. It deals with Environmental Matters (Articles 33-41) and specifically with Drought and Desertification Control (Articles 54-57). The procedure for the Implementation Agreement and promotion of regional cooperation are the two key features which may guide the INC-D in its work.

\section{DRAFT TEXT OF THE UNITED NATIONS CONVENTION ON COMBATING DESERTIFICATION AND MITIGATION OF DROUGHT}

(As prepared by the Secretariat of the Asian-African Legal Consultative Committee)

\section{TITLE OF THE CONVENTION}

So far, no discussion has been held in the INC-D about the title of the Convention. The AALCC Secretariat is of the view that this is an important matter which deserves due consideration at an early stage. Since this Convention is elaborated in accordance with the mandate given by the General Assembly Resolution 47/188 of 22 December 1992 , it would be appropriate if the title reflects that status. The title suggested by the AALCC Secretariat "The United Nations Convention on Combating Desertification and Mitigation of Drought" is based on that consideration.

\section{PREAMBLE}

Recalling the United Nations General Assembly resolutions 32/172 of 19 December 1977, 44/172 of 19 December 1989, 44/228 of 22 December 1989 and other relevant resolutions, as well as decisions adopted by the United Nations Conference on Environment and Development held in Rio de Janeiro in June 1992, in particular the recommendation by which the Conference invited the General Assembly to establish, under its auspices, an Inter-governmental Negotiating Comittee for the Elaboration of an International Convention to Combat Desertification in those Countries Experiencing Serious Drought and/or Desertification, particularly in Africa;

Recalling also General Assembly resolution 47/188 of 22 December 1992 by which it established the Intergovernmental Negotiating Committee for the Elaboration of a 
Convention to Combat Desertification with a view to finalizing such a Convention by June 1994;

Reaffirming the validity and relevance of the decisions adopted at the United Nations Conference on Environment and Development regarding measures to combat desertification and mitigate drought, and especially Chapter 12 of Agenda 21 "Managing fragile ecosystems: Combating desertification and drought";

Taking into account past experience particularly the efforts to implement the 1977 United Nations Plan of Action to Combat Desertification;

Appreciating the measures already taken or underway by states and organisations such as the United Nations Environment Programme, the United Nations Development Programme, the Food and Agriculture Organization, the United Nations Educational and Scientific Organization, the World Meteorological Organization, the United Nations Sudano-Sahelian Office, the International Fund for Agriculture Development at various levels to understand and address the problems of desertification and drought;

Considering that measures to combat desertification should be planned in the framework of sustainable development, with dynamic interaction between all development activities, and that measures to combat desertification must therefore form an integral part of the overall economic and social development strategies of the countries concerned;

Conscious of the adverse effects, including socio-economic, of land degradation in dryland areas, which affects a significant portion of the earth's surface and population and the need for proper management, utilization and conservation of resources and prevention of mass exodus and migration of populations;

Noting that economic and social developments and eradication of poverty are priority concerns of countries experiencing drought and desertification, particularly in Africa;

Determined to make concerted efforts to combat desertification and mitigate of drought, for the benefit of present and future generation;

Recognising the responsibility of countries affected by desertification to make necessary policy changes in their land tenure systems with a view to promoting sustainable land use practices and encouraging participation of rural communities and indigenous people in the development process;

Recognising also that in view of the widespread nature and complexity of the problems relating to desertification and/or drought and of the particular conditions affecting each region;

Stressing the need for promotion of sub-regional, regional and international cooperation to combat desertification;

Stressing also the need for effective international co-operation in the field of research and development and for applying ecologically sound technologies to combat desertification and mitigate drought;

Recognising the need to make available further and additional financial resources to countries affected by drought and desertification, particularly in Africa;

Recognising also the vital role played by the local people, particularly the women in combating desertification and affirming the need to ensure that they participate fully and effectively in planning and implementation of measures to combat desertification amd mitigate drought; 
Decides to conclude an international convention on combating desertification and mitigation of drought as well as appropriate instruments adapted to the specific needs of different regions;

\section{Explanatory Note}

Since the discussion concerning the Preamble will continue until a late stage of negotiations, the AALCC draft text on Preamble sets out only a tentative list, which may be further shorthened or elaborated as need be. There are issues such as poverty eradication, mitigation of debt etc., which could find place in the Preamble.

\section{Article 1}

Definitions

(a) 'Desertification' is a process of land degradation in arid, semi-arid and dry subhumid areas resulting from various factors, including climatic variation and human activities.

(b) 'Drought' refers to a sustained period of water deficit in particular areas, perhaps lasting a few months or even many years and can be classified according to a number of criteria involving several variables used either alone or in combination such as meteorological drought, agricultural drought and hydrological drought.

(c) 'Combating desertification' means all activities aimed at halting and reversing the process of desertification as defined in this Convention.

(d) 'Drought mitigation'.

(e) 'Regional economic integration organisation' means an organisation constituted by sovereign states of a given region which has competence in respect of matters governed by this convention, its Protocols or Annexes and has been duly authorised, in accordance with its internal procedures to sign, ratify, accept, approve or accede to the instruments concerned.

\section{Explanatory Note}

No attempt has been made to give a complete list of definitions. The AALCC Secretariat is of the view that the definition of desertification as set out in Agenda 21 is appropriate. For the definitions of other terms which may be necessary to be defined in the context of the Convention, advice could be sought from World Meteorological Organization and such other organisations engaged in similar work. Some elements of the OAU and the ECA texts have also been included in the AALCC text. The definition of the term 'Regional Economic Integration Organization' is the standard one as set out in the Climate Change and Biodiversity Conventions.

\section{Article 2}

Principles

(a) States have, in accordance with the Charter of the United Nations and Principles of International Law, the sovereign right to exploit their own resources pursuant to their own environmental and developmental policies, and the responsibility to ensure that 
activities within their jurisdiction or control do not cause damage to the environment of other states or areas beyond the limits of national jurisdiction.

(b) The Principle of Sovereignty of States shall prevail in all international programmes and measures for combating desertification and mitigate drought.

(c) The Principle of shared, but differentiated responsibility in promoting and implementing the provisions of the Convention.

(d) The right to development must be realized in such a way as to satisfy the development and environmental needs of present and future generations.

(e) States should co-operate in promoting an open international economic system that will facilitate economic growth and sustainable development in all countries, thus enabling particularly those countries which are affected by drought and desertification to take effective action.

\section{Explanatory Note}

It appears that the divergent views on the inclusion of an article on Principles could be narrowed down if the list is precise and the principles to be included are generally acceptable. The AALCC Secretariat draft text is a tentative one. There are certain principles in the OAU draft (A/AC. 241/12, paragraph 29) which may be considered in this context.

\section{Article 3 \\ Objective}

The overall objective of the Convention is to promote and strengthen international co-operation to combat desertification and mitigate drought more effectively in the regions affected by such problems.

The immediate objectives are: to prevent land degradation and the destruction of ecosystems; to establish a framework of co-operation and partnership based on mutual interest; to strengthen capacity building at the local, national, sub-regional and regional levels; and to establish a system to monitor and review the commitments of the parties to the Convention and its other instruments.

\section{Explanatory Note}

Perhaps the AALCC draft may be considered as short and precise. In view of the pending decision on the nature and time-table for the conclusion of regional instruments, it is felt that elaboration of the article on objective could be deferred until a clear view appears on that issue.

\section{Article 4 \\ Commitments}

1. The Contracting Parties, taking into account their specific national and regional development priorities, objectives and circumstances, shall:

(a) formulate, implement, publish and periodically update their national and, where appropriate, regional programmes containing measures to mitigate drought and combat desertification; 
(b) Develop and strengthen the knowledge base and information for regions prone to desertification and drought, including the economic and social aspects of these ecosystems;

(c) Strengthen regional and global systematic observation networks linked to the development of national system for the observation of land degradation and desertification caused both by climatic fluctuations and by human impact and identify priority areas for action;

(d) Support the integrated data collection and research work of programmes related to desertification and drought;

(e) Support national, regional, sub-regional activities in technology development and dissemination, training and programme implementation to arrest dryland degradation facilitate the mobilization of adequate financial resources for providing technical and financial assistance to developing countries affected by drought and desertification;

(f) Facilitate the mobilization of adequate financial resources for providing technical and financial assistance to developing countries affected by draught and desertification.

2. The Contracting Parties experiencing drought and desertification problems shall:

(a) Develop comprehensive anti-desertification programmes and integrate them into national development plans and national environmental planning;

(b) Develop comprehensive drought preparedness and drought-relief schemes for drought-prone areas and, where necessary, design programmes to cope with environmental refugees;

(c) Develop land use models based on local practices for the improvement of such practices with a view to preventing land degradation;

(d) Promote integrated research programmes on the protection, restoration and conservation of water and land resources and land-use management based on traditional approaches, where feasible;

(e) Develop and adopt, through appropriate national legislation, and introduce institutionally, new and environmentally sound development oriented land use policies;

(f) Strengthen national institutional capabilities to develop and implement appropriate programmes to combat desertification and mitigate of drought;

(g) Co-ordinate and harmonise the implementation of programmes and projects funded by the United Nations Agencies, Inter-governmental and Non-governmental organizations that are directed towards combating desertification and mitigation of drought;

(h) Encourage and promote popular participation and environmental education, focussing on desertification control and the management of the effects of drought;

(i) Establish mechanisms to ensure that land users, particularly women are the main actors in implementing improved land use, including agroforestry systems, in combatting land-degradation.

3. The Contracting Parties, especially those facing serious drought and desertification thall, in addition to the measures mentioned in Paragraph 2, give priority and mobilizes financial, technical, material and human resources to deal with the situation.

\section{Explanatory Note}

Since the deliberations on this crucial issue just began at the Geneva Session, it is considered rather premature to draft concrete provisions. Besides the problem 
concerning its format, it is also not clear as to what type and categories of commitments would emerge from future deliberations. It is the key issue in the Convention and to arrive at any consensus there has to be give and take approach. The AALCC Secretariat draft merely identifies a few provisions which need to be considered and elaborated in the light of subsequent developments.

\section{Article 5 \\ Regional and Sub-regional Co-operation}

The Contracting Parties shall endeavour to promote:

(a) Regional and sub-regional co-operation in the areas concerning combating desertification and mitigation of drought;

(b) Strengthening, and where necessary, establishment of regional and sub-regional centres as well as networks of research monitoring and systematic observation including early warning systems for drought and desertification;

(c) Exchange of information, experiences and know-how relating to policy and programme alternatives in fields such as land-tenure, resource management and use of indigenous technologies;

(d) The establishment of modalities for joint effective management and use of shared resources such as grazing lands, river and lake basins;

(e) Mobilization of technical and financial support and resources necessary for the formulation, implementation, follow-up and evaluation of regional and sub-regional plans of actions.

\section{Article 6 \\ Research and Training}

The Contracting Parties, taking into account the special needs of developing countries affected by drought and desertification, shall:

(a) Establish, promote and support research and programmes concerning scientific and technical education and training for monitoring, prevention and control of desertification and mitigation of drought;

(b) The Conference of the Parties at its first meeting shall determine how to establish a clearing house mechanism to promote and facilitate a standardized system for observing and reporting data, as well as other forms of technical and scientific cooperation.

Article 7

\section{Technology Transfer and Co-operation}

The Contracting Parties shall facilitate access to and transfer of ecologically friendly anti-desertification technologies on a fair, equitable and preferential basis by encouraging programmes of co-operation and assistance to the developing countries affected by drought and desertification. Such programmes shall take into account the applicability of technology transfer to local communities and encourage active 
involvement of the private sector, aiming at the development and transfer of appropriate technologies to combat desertification and mitigate drought.

\section{Article 8}

Capacity building

The Contracting Parties shall:

(a) establish and maintain programmes for the development and strengthening of national capabilities by supporting scientific education and training for the specific needs of the developing countries particularly in Africa; and

(b) take all measures to ensure the participation of local populations, particularly women, youth and children.

\section{Article 9}

\section{Education and Public Awareness}

The Contracting Parties shall:

(a) promote and encourage awareness campaigns for combating desertification and mitigate drought through the electronic and print media;

(b) co-operate in and promote, at the international level, the development and exchange of educational and public awareness material on the causes, effects and measures to deal with drought and desertification.

\section{Explanatory Note}

The texts of these four articles dealing respectively with Regional and Sub-regional co-operation, Research and Training, Technology Transfer and Co-operation and Capacity Building reflect the emerging consensus. The AALCC Secretariat draft is by no means an exhaustive one. Depending upon the text of articles on commitments the substance of these four articles would need to be considered again.

\section{Article 10}

\section{Financial Mechanism}

(a) There shall be a mechanism for the provision of financial resources to developing country parties for the purposes of this Convention on a grant or concessional basis. The mechanism shall function under the authority and guidance and be accountable to the Conference of Parties which shall at its first meeting, decide upon the institutional structure for such a mechanism and determine the policy, strategy, programme priorities and eligibility criteria relating to access to and utilization of such resources. The mechanism so established shall take into account the importance of burden sharing among the parties to the Convention;

(b) The Contracting Parties may seek financial assistance from the Global Environment Facility (GEF) for the implementation of any programme concerning combating desertification and mitigate drought provided such programmes are related to or lie within the areas identified by the GEF for its financial assistance; 
(c) The Contracting Parties shall be free to seek or provide any financial resources related to the implementation of the provisions of the Convention through bilateral, regional and other multilateral channels.

\section{Explanatory Note}

INC-D Negotiators will find this issue as the toughest nut to crack. The divergence of views between the developed and developing countries in regard to financial resources is too wide. If it becomes possible to involve GEF with this Convention, it will be a real breakthrough. There is no indication whether the developed countries would be prepared to extend generous financial assistance to implement the lofty provisions in the Convention. The AALCC Secretariat, keeping this reality in view, has followed the guidelines established in the Biodiversity Convention (Article 20) in preparing the text of this article.

Article 11

\section{Co-ordination and Co-operation}

The Contracting Parties shall take measures to promote efficient co-ordination and co-operation at all levels.

\section{Explanatory Note}

The AALCC Secretariat is not sure whether such a provision is necessary. However, this theme is the basic purpose of the Convention. Since the compilation (A/AC.241/12) contained such a provision (paragraph 108) and there was some discussion on this issue during the Geneva Session, the inclusion of such a provision in general terms may be considered useful.

Article 12

Relationship with other Conventions

(a) The Contracting Parties recognise the close link that exists between the realization of the objectives of this Convention and those pursued by other legal instruments particularly the Framework Convention on Climate Change and the Convention on Biodiversity.

(b) In this regard, the provisions of this Convention shall be complementary to and in no manner affect the rights and the obligations of the Parties inherent in any international legal instrument related to objectives of this Convention.

\section{Explanatory Note}

The objective of the proposed Convention on Combating desertification is in many ways close to other environmental Conventions, particularly the Climate Change and the Biodiversity Conventions. In order to recognise and strengthen such relationship, it would be useful to stipulate a provision to this effect. 
Article 13

Conference of the Parties

(i) A Conference of the Parties is hereby established.

(ii) The Conference of the Parties as the supreme decision-making body within this Convention shall keep under regular review the implementation of the Convention and of any related instruments that the Conference of the Parties may adopt. It shall make, within its mandate, the decisions necessary to promote the effective implementation of the Convention. To this end, it shall:

(a) Periodically examine the commitments of the Parties and the institutional arrangements under the Convention, in the light of the objective of the Convention, the experience gained in its implementation and the evolution of scientific and technological knowledge;

(b) Promote and facilitate the exchange of information on measures adopted by the Parties to implement the Convention, taking into account the differing circumstances, responsibilities and capabilities of the Parties and their respective commitments under the Convention; and adopt such measures as necessary for the successful implementation of the objectives of the Convention;

(c) Agree upon and adopt, by consensus, rules of procedure and financial rules for itself and for any subsidiary bodies; and

(d) Exercise such other functions as required for the achievement of the objectives of the Convention as well as other functions assigned to it under this Convention.

(iii) The first session of the Conference of the Parties shall be convened.by the $\mathrm{Ad} \mathrm{Hoc}$ Secretariat referred to in Article 23 and shall take place not later than one year after the entry into force of the Convention. Thereafter, ordinary sessions of the Conference of the Parties shall be held every year unless otherwise decided by the Conference of the Parties.

(iv) Extraordinary sessions of the Conference of the Parties shall be held at such other times as may be deemed necessary by the Conference, or at written request of any party, supported by one third of the membership of the Conference, within two months of the request being communicated to the Parties by the Secretariat.

(v) The United Nations, its specialized agencies as well as any State member thereof or observers thereto not Party to the Convention, may be admitted by the Conference of the Parties as observers. Any body or agency, whether national or international, governmental or nongovernmental, which is qualified in matters covered by the Convention, and which has informed the Secretariat of its wish to be represented at a session of the Conference of the Parties as an observer may request to be so admitted unless at least one third of the Parties present object. The admission and participation of observers shall be subject to the rules of Procedure adopted by the Conference of the Parties. 


\section{Explanatory Note}

The AALCC Secretariat draft is based on OAU draft paragraph 116 (A/AC.241/12).

\section{Article 14 \\ Secretariat}

(i) A Secretariat is hereby established.

(ii) The functions of the Secretariat shall be:

(a) To make arrangements for sessions of the Conference of the parties and its subsidiary bodies established under the Convention and to provide them with services as required in accordance;

(b) To compile and transmit reports submitted to it;

(c) To facilitate assistance to the Parties, particularly the affected Parties, on request, in the compilation and communication of information required in accordance with the provisions of the Convention;

(d) To prepare reports on its activities and present them to the Conference of the Parties;

(e) To ensure the necessary coordination with the secretariats of other relevant international bodies and conventions;

(f) To enter, under the overall guidance of the Conference of the Parties, into such administrative and contractual arrangements as may be required for the effective discharge of its function; and

(g) To perform other secretariat functions specified in the convention and in any of its protocols and annexes and such other functions as may determined by the Conference of the Parties.

(iii) The Conference of the Parties, at its first sessions, shall designate a permanent secretariat and make arrangements for its functions.

\section{Explanatory Note}

The source of the AALCC draft text is the OAU draft (Paragraph 120, A/AC.241/12) which is identical to Article 8 of the Climate Change Convention.

\section{Article 15}

\section{Scientific and Technological Council}

(a) A Scientific and Technological Council is hereby established as a subsidiary organ of the Conference of the Parties. It shall be made up of 10 Members appointed by the Conference of the Parties for a renewable period of three years;

(b) At the request and under supervision of the Conference of the Parties, it shall provide scientific and technical opinions on all issues that might assist the Conference of the Parties in promoting and pursuing the objectives of the Convention;

(c) It shall cooperate with relevant and competent international organisations and agencies as may be determined by the Conference of Parties;

(d) It shall submit its activity reports to the Conference of the Parties. 


\section{Explanatory Note}

The AALCC Secretariat text is based on the OAU text in paragraph 124 (a) (A/AC.241/12). During the discussions in Geneva Session it was suggested that the Convention instead of proliferating institutions, should strengthen the existing institutions. However it has been suggested that the regime established by Convention should operate independently. At some stage it would be inevitable that new institutions will have to be established particularly for promoting research and monitoring implementation of the Convention. The Convention should provide for such eventuality. To begin with, as and when the Convention comes into force, a Scientific and Technological Council comprising 10 members nominated by the COP from different regions might be the only additional institution. The UNEP has played a significant catalytic role in this field. It could be entrusted with major responsibilities for promoting research, data collection and public awareness programmes. In this context, inter-agency co-operation and co-ordination among the United Nations Agencies and various international and non-governmental organisation is of equal importance. Besides avoiding duplication, such combined effort could render useful assistance to the Scientific and Technological Council in taking a concerted approach.

Article 16

Adoption of Protocols

(a) The Conference of the Parties may, at any of its regular sessions, adopt protocols to the Convention.

(b) The text of any protocol that is proposed shall be communicated to the parties by the Secretariat at least six months before the session.

(c) The rules governing the entry into force of a protocol shall be laid down in the protocol itself.

(d) Only the parties to the Convention may be parties to a protocol.

(e) Only the parties to a protocol shall take decisions under that protocol.

(f) No state nor any regional economic integration organization may become a party to a protocol without being or simultaneously becoming a party to the Convention.

\section{Explanatory Note}

The AALCC Secretariat text is based on the text set out in paragraph 133 (A/AC.241/12).

\section{Article 17}

Amendments

(a) Amendments to this Convention may be proposed by any Contracting Party. Amendments to any protocol may be proposed by any Party to that Protocol.

(b) Amendments to this Convention shall be adopted at a meeting of the Conference of the Parties. Amendments to any protocol shall be adopted at a meeting of the Parties to the Protocol in question. The text of any proposed amendment to this Convention or to any protocol, except as may otherwise be provided in such protocol shall be communicated to the Parties to the instrument in question by the Secretariat at least six 
months before the meeting at which it is proposed for adoption. The Secretariat shall also communicate proposed amendments to the signatories to this Convention for information.

(c) The Parties shall make every effort to reach agreement on any proposed amendment to the Convention or to any protocol by consensus. If all efforts at consensus have been exhausted, and no agreement reached, the amendment shall, as a last resort, be adopted by a two-third majority vote of the Parties to the instrument in question present and voting at the meeting, and shall be submitted by the Depositary to all Parties for ratification, acceptance or approval.

(d) Ratification, acceptance or approval of amendments shall be notified to the Depositary in writing. Amendments adopted in accordance with paragraph (3) above shall enter into force among Parties having accepted them on the ninetieth day after the deposit of instruments of ratification, acceptance or approval by at least two thirds of the Contracting Parties to this Convention or of the Parties to the protocol concerned, except as may otherwise be provided in such a protocol. Thereafter the amendments shall enter into force for any other Party on the ninetieth day after that Party deposits its instrument of ratification, acceptance or approval of the amendments.

(e) For the purposes of this Article, Parties present and voting means Parties present and casting an affirmative or negative vote.

\section{Article 18 \\ Adoption and Amendment of Annexes}

(i) The annexes to this Convention or to any protocol shall form an integral part of the Convention or such protocol, as the case may be, and, unless expressly provided otherwise, a reference to this Convention or its protocols constitutes at the same time a reference to any annexes thereto.

(ii) Except as may be otherwise provided in any protocol with respect to its annexes, the following procedure shall apply to the proposal, adoption and entry into force of annexes to this Convention or of annexes to any protocol:

(a) Annexes to this Convention or to any protocol shall be proposed and adopted according to the procedure laid down in Article 17, paragraphs (b), (c) and (d).

(b) Any Party that is unable to approve an additional annex to this Convention or an annex to any protocol to which it is a Party, shall so notify the Depositary in writing, within one year from the date of the communication of the adoption by the Depositary. The Depositary shall without delay notify all Parties of any such notification received. A Party may at any time withdraw a previous declaration of objection and the annexes shall thereupon enter into force for that Party.

(c) On the expiry of one year from the date of the communication of the adoption by the Depositary, the annex shall enter into force for all Parties to this Convention or to any protocol concerned which have not submitted a notification it accordance with the provisions of sub paragraph (b) above.

(d) The proposal, adoption and entry into force of amendments to annexes to this Convention or to any protocol shall be subject to the same procedure as for 
the proposal, adoption and entry into force of annexes to the Convention or annexes to any protocol.

(e) If an additional annex or an amendment to an annex is related to an amendment to this Convention or to any protocol, the additional annex or amendment shall not enter into force until such time as the amendment to the Convention or to the protocol concerned enters into force.

\section{Explanatory Note}

The AALCC Secretariat text is identical to Article 30 of the Bio-diversity Convention and Article 16 of the Climate Change Convention. In the event the INC-D decides to conclude annexes as the regional instruments, the procedure for adoption of such regional annexes may be different and this will necessitate redrafting of this Article accordingly.

\section{Article 19}

\section{Settlement of Disputes}

In the event of a dispute between any two or more Parties concerning the interpretation or application of the Convention, the Parties concerned shall seek a settlement of the dispute through negotiation or any other peaceful means of their own choice.

\section{Explanatory Note}

The AALCC Secretariat text is identical to OAU drafting proposal set out in paragraph 142 (A/AC.241/12).

Article 20

Right to Vote

1. Each Party to the Convention shall have one vote, except as provided for in paragraph 2 below.

2. Regional economic integration organisations, in matters within their competence, shall exercise their right to vote with a number of votes equal to the number of their member States that are Parties to the Convention. Such an organisation shall not exercise its right to vote if any of its member States exercises its right and vice versa.

\section{Explanatory Note}

This is identical to Article 18 of the Climate Change Convention and Article 31 of the Biodiversity Convention. 


\section{Article 21}

The Secretary-General of the United Nations shall be the Depositary of the Convention, Protocols and Annexes adopted in accordance with Articles 16 and 18 respectively.

\section{Article 22}

This Convention shall be open for signature by States that are Members of the United Nations or of any of its specialized agencies or that are parties to the Statute of the International Court Justice and by regional economic integration organisations, at New York, during the forty ninth Session of the General Assembly on . . . . 1994 and shall remain open for signature until . . . .

\section{Article 23}

\section{Interim Arrangements}

The Secretariat functions referred to in Article 14 will be carried out on an interim basis by the Secretariat established by the General Assembly of the United Nations in its Resolution 47/188 of 22 December 1992, until the completion of the first session of the Conference of Parties.

\section{Article 24}

\section{Ratification, Acceptance, Approval or Accession}

1. The Convention shall be subject to ratification, acceptance, approval or accession by States and by regional economic integration organisations. It shall be open for accession from the day after the date on which the Convention is closed for signature. Instruments of ratification, acceptance, approval or accession shall be deposited with the Depositary.

2. Any regional economic integration organization which becomes a Party to the Convention without any of its member States being a Party shall be bound by all the obligations under the Convention. In the case of such organisations, one or more of whose member States is a Party to the Convention, the Organisation and its member States shall decide on their respective responsibilities for the performance of their obligations under the Convention. In such cases, the Organisation and the member States shall not be entitled to exercise rights under the Convention concurrently.

3. In their instruments of ratification, acceptance, approval or accession, regional economic integration organisations shall declare the extent of their competence with respect to the matters governed by the Convention. These organisations shall also inform the Depositary, who shall in turn inform the Parties, of any substantial modification in the extent of their competence. 
Article 25

Entry into force

1. The Convention shall enter into force on the ninetieth day after the date of deposit of the (thirtieth) (fiftieth) instrument of ratification, acceptance approval or accession.

2. For each State or regional economic integration organisation that ratifies, accepts or approves the Convention or accedes there[to] after the deposit of the (thirtieth) (fiftieth) instrument of ratification, acceptance, approval or accession, the Convention shall enter into force on the ninetieth day after the date of deposit by such State or regional economic integration organisation of its instrument of ratification, acceptance, approval or accession.

3. For the purposes of paragraphs 1 and 2 above, any instrument deposited by a regional economic integration organisation shall not be counted as additional to those deposited by member States of the organisation.

Article 26

Reservations

No reservations may be made to the Convention.

Article 27

Withdrawal

1. At any time after three years from the date on which the Convention has entered into force for a Party, that Party may withdraw from the Convention by giving written notification to the Depository.

2. Any such withdrawal shall take effect upon expiry of one year from the date of receipt by the Depositary of the notification of withdrawal, or on such later date as may be specified in the notification of the withdrawal.

3. Any Party that withdraws from the Convention shall be considered as also having withdrawn from any protocol or annex to which it is a Party.

\section{Article 28}

Authentic Texts

The original of the Convention, of which the Arabic, Chinese, French, Russian and Spanish texts are equally authentic, shall be deposited with the Secretary-General of the United Nations.

In witness whereof the undersigned, being duly authorised to that effect, have signed this Convention.

Done at New York this . . . . 1994." 
47. Doc. No. TOKYO/94/7a reviews work carried out during 1993 by the Intergovernmental Negotiating Committee (INC) to prepare an effective Framework Convention on Climate Change (originally established by UN General Assembly resolution 45/212 of 21 December 1990, and continued in operation after adoption of the Framework Convention at UNCED, by UN General Assembly resolution 47/195 of 22 December 1992), and by the Intergovernmental Committee on the Convention on Biological Diversity (ICCBD). The Secretariat notes the possibility that the Climate Change Convention would receive during 1994, the 50 ratifications needed to bring it into force, and the invitation of the German Government to act as host to the first session of the Conference of Parties from 28 March 7 April 1995, in Berlin (Doc. No. TOKYO/94/7a, pages 12-13; Report, page 49). It also notes that the Convention on Biological Diversity had been signed by 167 countries as of 1 December 1993 and, having been ratified by 37 countries, entered into force on 29 December 1993 (Doc. No. TOKYO/94/7a, page 15). Doc. No. AALCC/XXXIII/TOKYO/94/10 contains on pages 5, 14 and 15, observations concerning efforts to draft a Convention on Desertification.

48. The Assistant Secretary-General of AALCC, introducing the item inter alia announced that on the basis of resources donated by Saudi Arabia and Myanmar, and a pledge by Turkey, a Special Fund for the Environment had been created within the AALCC Secretariat.

\section{Decision}

49. Having considered the documentation before it and the introductory statement of the Assistant Secretary-General (Report, pages 147 150), the Committee adopted a decision (Report, pages 235-6) which, inter alia, underscores the need for Member States of AALCC to participate actively in the relevant meetings on the Environment; expresses appreciation to donors and prospective donors to AALCC's Special Fund for the Environment, and directs the Secretariat to continue to monitor and report upon progress in environmental matters, in particular implementation of Agenda 21.

\subsection{United Nations Decade of International Law}

50. The Committee had before it a document prepared by the Secretariat entitled United Nations Decade of International Law (Doc. No. AALCC/ XXXIII/TOKYO/94/9) outlining the Committee's activities which contributed 
to attainment of the objectives of the Decade. Annexed to it is the "Report of the [UN] Secretary-General on a preliminary operational plan for a possible United Nations congress on public international law" (UN Doc. No. A/48/435).

51. The Secretary-General of $A A L C C$ introducing the item, noted the Committee's contribution to preparation of the International Conference on International Legal Issues arising under the UN Decade of International Law, to be hosted by the State of Qatar in March 1994, as well as Secretariat initiatives in support of the Decade, including a survey of ratifications of key international conventions with a view to assisting Member States to accede to or ratify them; and a study of reservations which Member States may have made to those conventions.

52. Members who spoke, acknowledged the importance of the Decade as a means of promoting the development and dissemination of international law, mentioning peaceful settlement of disputes as a subject which should receive special attention, and welcoming preparations for the United Nations Congress on Public International Law, expected to convene in 1995.

\section{Decision}

53. Discussion of this item (Report, pages 100-106) was followed by adoption of an essentially procedural decision (Report, pages 238-239).

\subsection{World Conference on Human Rights: follow up}

54. The Committee had before it a document prepared by the Secretariat entitled the World Conference on Human Rights and its follow up (Doc. No. AALCC/XXXIII/TOKYO/94/12) and containing a description of the World Conference on Human Rights held at Vienna from 14 to 25 June 1993 in implementation of UN General Assembly resolution 45/155 of 18 December 1990, attended by some 163 States including all 44 Member States of AALCC, as well as the content of the Declaration and Programme of Action adopted by consensus at the Conference. The document lists as controversial the following issues: (1) creation of the position of a United Nations 'High Commissioner for Human Rights' and associated powers and functions (ultimately left for consideration as a matter of priority by the UN General Assembly at its Fortyeighth Session); (2) the universal character of human rights, and the contention 
that national and regional particularities/specificities should be taken into account in the implementation and observance of human rights; (3) the right to development as a human right; (4) the linkage between human rights and development assistance - the question whether bilateral or multilateral economic assistance should be conditional on the recipient's fulfilment of conditions related to implementation of civil and political rights; (5) the right to self determination: its definition and implementation; and (6) financing the UN Centre for Human Rights. The document's summary of AALCC's ideas on human rights (based on the Committee's Kampala Declaration, see 3 AsYIL, pages 297-300, reads (in part):

“. . .

42. Human rights, development and international peace are interdependent. Peace and security both at the national and international level remain the condition sine qua non for the realization and enjoyment of all indivisible and inalienable human rights in full and substantial measure. Members of the international society must therefore reaffirm their desire to save the present and succeeding generations from the scourge of wars and armed conflicts, both international and domestic, as well as to maintain international peace and security in accordance with the purposes and principles of the Charter of the United Nations.

43. In the developing countries poverty is one of major obstacles hindering the enjoyment of human rights. The fact that almost three fourth's of the Planet's population suffer from malnutrition, disease and poverty should be a matter of concern for all of us. The poor socio-economic conditions resulting partly from the transfer of resources to the servicing of external debts and from the disparity in the terms of international trade, hinder both the process of development and the realization of human rights in the developing and least developed countries. We believe that development is not merely a means to economic growth but a process to enlarging people's choices. We also believe that the right to development is an inalienable human right, and the vital importance of economic and social development to the full enjoyment of human rights should be further recognized and underscored. All states therefore must cooperate in the essential task of eradicating poverty for the universal realization of human rights.

44. Development and the environment are intrinsically linked and should not be considered in isolation from each other. Development should not be such a manner as would endanger the environment. In this context, the right of an individual, or human right, to a safe and sound environment as incorporated in the Kampala Declaration needs to be emphasized. This may at first blush appear to be a novel concept. But it is far from being so since the root, and 
basis of both concepts viz. international environmental law and sustainable development is inter-generation equity. The right to a safe and healthy environment may therefore require to be progressively developed and codified.

45. The indivisibility and inter-dependence of human rights have been recognized and must be given effect in policy formulation and implementation. Civil and political rights cannot be dissociated from economic, social and cultural rights. The satisfaction of economic, social and cultural rights is major factor for this enjoyment of civil and political rights.

46. The primary responsibility for implementing human rights is at the national level. Consequently, the most effective system or method of promoting and protecting these rights has to take into account the nation's history, culture, tradition, norms and values. Whilst the international community should be concerned about the observation of human rights, it should not seek to impose or influence the adoption of the criteria and system that are only suitable to some countries on developing countries. On the other hand, no state should manipulate its sovereignty to deny the inalienable rights of its citizens and expect silence from the international community.

47. International cooperation is vital to the promotion of human rights. It is therefore important that states reaffirm their commitment to the principle of universality, objectivity and non-selectivity of all human rights as a just and balanced approach in this regard. Palletisation of human rights, application of double standards, interference in the internal affairs of others, are a challenge to international cooperation in the field of human rights, and must be avoided.

48. The rule of law in the administration of justice is a prerequisite to full enjoyment of human rights. The international community should reaffirm the significant role that administration of justice should play in the promotion and protection of human rights as well as in the development process, and training, equipment and incentives should be provided to those state agencies [which are] involved in the administration of justice within the developing countries on the basis of their need and request. To this end, governments, regional and international financial institutions and the donor community are urged to provide necessary resources.

49. All states that have not already ratified or acceded to the international human rights conventions should endeavour to do so in the course of the United Nations Decade of International Law. In doing so, such states would be promoting the objectives of acceptance and respect for the principles of international law and also would ensure universal adherence to the international instruments which have set up norms covering a broad spectrum of human rights. This is of vital significance since despite the fact that most 
of the international conventions on human rights issues are in force, their status in terms of the number of states parties can scarcely be considered as widespread or universal. Regional human rights instruments should be employed to supplement concepts and norms enumerated in the universal instruments.

50. In every society, there is a class of persons who may require special consideration. The promotion and protection of human rights of vulnerable groups such as women, children, refugees, disabled, migrant workers, minorities and indigenous people should be given special attention and priority.

51. The United Nations system in the field of human rights is urged to use existing mechanisms and resources effectively and efficiently. The improvement of existing institutional mechanisms and the enhancement of their co-operation and coordination should be undertaken. All the members of the international community are called upon to contribute additional financial and other resources for human rights activities both at national and international levels."

55. The Assistant Secretary-General, introducing the item, recalled that the AALCC's Kampala Declaration on Human Rights had been submitted to the Preparatory Committee for the Conference, and that some ideas from the Declaration had been reflected in the final documents of the Conference. He said that two issues should be given urgent attention: the establishment of the office of United Nations High Commissioner for Human Rights, which had been effected by General Assembly resolution without vote on 20 December 1993 although the idea had been strongly opposed by many Asian, African and Latin American countries; and the promotion of universal acceptance of multilateral human rights conventions. As to the first issue, he observed that although the office of High Commissioner for Human Rights had originally been conceived by its proponents as having discretionary powers to send factfinding missions into countries accused of human rights violations, it had been agreed ultimately that the office would have no such powers. On the second issue, he said that adherence to human rights conventions had been generally very slow, but that adherence by the Member States of AALCC had in many instances been well below the global average. He encouraged all Member States of AALCC to ratify or accede to these conventions in implementation of the Vienna documents urging that fresh efforts be made to identify obstacles to universal acceptance and to seek ways and means of overcoming them.

56. The delegate of Japan said that, while human rights may fall within the domestic jurisdiction of a State, and while the latter had primary responsibility 
for guaranteeing those rights, it should be recognized that human rights was a universal value common to all mankind and that, as had been stated in the Vienna Declaration and Programme of Action, the promotion and protection of all human rights is a legitimate concern of the international community. Welcoming the creation of the office of UN High Commissioner for Human Rights, he said his Government recognized the necessity of strengthening the capacity of the United Nations to promote and protect human rights, and to increase substantially the resources available to it for the purpose.

57. The delegate of China said that the Vienna Declaration represented a consensus on future activities by the international community to promote and protect human rights. The document reflected both shared understandings and some differences of opinion among countries. In his Government's view, the following aspects should be taken into consideration in implementing the Vienna documents:

(i) equal importance should be attached to the various recommendations contained in those documents, so as to ensure their comprehensive implementation;

(ii) efforts should be made to promote co-operation among all States in the field of international human rights on the basis of equality and mutual respect; and

(iii) the international community should continue to be mobilized to address and end large scale violations of human rights resulting from colonialism, racism and foreign aggression and occupation, so as to create conditions for the developing countries to raise their people's living standards and fully realise their right to development at an early date.

58. Continuing, the delegate of China said that each country had its own political, economic and historical character, and was at a different stage of economic development, all of which gave rise to special national conditions and traditions. Each country had to deal with its own human rights issues calling for urgent solutions, and in order to do so, had to establish its own approaches and priorities. For China, as for the other developing countries, a citizen's right to subsistence and development was of primary concern. Therefore, there should be respect for the different ways in which the concept of human rights was understood in different countries, taking into account their national conditions, and such an attitude should constitute the cornerstone of exchanges and co-operation in the field of human rights at the international level. Different social systems should be respected, and the application of selectivity and double standards avoided. He said his Government was ready to work with other members of the international community on the basis of 
such mutual understanding and respect, to strengthen international co-operation with a view to further promoting and protecting human rights.

59. The delegate of Sudan, while agreeing with the delegate of Japan that human rights were universal and should be respected by all, observed that violations of human rights were occurring in many countries. Such violations, he said, should be condemned wherever they occurred, and there should be no selectivity, bias and the application of double standards which led to the abuse and victimization of small countries, especially through the mass media. While accepting the universality of the concept of human rights, he could agree that the culture, religion and traditional values of peoples should be taken into account, and recalled the role of China at the Vienna Conference in promoting solidarity among the developing countries to combat designs against them.

60. Continuing, the delegate of Sudan declared that nongovernmental organizations paid for by Western governments had been allowed to participate in the Vienna Conference to further their design to dominate the world. In his view, it was the solidarity of the developing countries and their regional declaration on human rights issues that had saved the Conference from abuse. As to creation of the office of UN High Commissioner for Human Rights, while his Government did not reject the idea, it would wish to qualify the scope of the High Commissioner's role and powers, to prevent, for example, that office being given the power to impose or enforce sanctions under Chapter VII of the UN Charter, and to prevent misuse of its powers. He observed that while the Security Council was sometimes used to impose sanctions in the name of democracy, it did not itself function along democratic lines.

61. The delegate of India reaffirmed his Government's commitment to the promotion and implementation of human rights, and recalled the recent establishment of a national Human Rights Commission. He said that the developing countries were engaged in promoting human rights; however, such action had been voluntary, and could not be imposed.

\section{Decision}

62. In the decision (Report, pages 241-3) which followed discussion of the item (Report, pages 126-136) the Committee ${ }^{2}$ inter alia

2 The Delegate of Japan expressed the following reservation to the Decision: "Since paragraph I of the resolution refers to the Kampala Declaration, my delegation reiterates the observations made at the time of its adoption. We recognise that social and economic development often 
“. .

1. Reaffirms the basic principles incorporated in Kampala Declaration on Human Rights adopted by the Committee on 6th February 1993;

2. Reaffirms also the solemn commitment to promote universal respect for and enjoyment by all of human rights and fundamental freedoms;

3. Welcomes the successful conclusion of the Second World Conference on Human Rights, and calls for the full and effective implementation of the final document of the Conference;

4. Reiterates the vital importance of the universal acceptance of international human rights treaties adopted within the framework of the United Nations system, and other treaties adopted within the framework of other regional organizations;

5. Urges Member States to devise effective action plans and concrete measures to speed up the process towards that goal. All States are encouraged to ratify or accede to those treaties with the aim of universal acceptance;

6. Recommends that priority be accorded to the following conventions: International Covenant on Economic, Social and Cultural Rights (1966), International Covenant on Civil and Political Rights (1966), International Convention on the Elimination of All Forms of Racial Discrimination (1966), convention against Torture and other Cruel, Inhuman and Degrading Treatment or Punishment (1984), Convention relating to the Status of Refugee (1951) and its Protocol (1967), Convention on the Elimination of All Forms of Discrimination against Women (1979), and Convention on the Right of the Child (1989);

7. Acknowledges the creation of the post of High Commissioner for Human Rights and requests Member States to cooperate with the High Commissioner who shall act in accordance with the resolution of the General Assembly;

8. Stresses the obligation to respect the sovereignty, territorial integrity and domestic jurisdiction of Member States, while promoting universal respect for and observance of all human rights;

9. Affirms that the acknowledgement and promotion of the right to development would greatly enhance respect and observance of human rights in general;

contributes to ensuring respect for human rights. At the same time, however, fundamental freedoms and human rights should not be sacrificed for the sake of development, but they should be respected by all countries regardless of the degrees of their political and economic development.

As for the problem of human rights and its relationship with the principle of non interference in the internal affairs of other countries my Government is of the view that, since respect for human rights is a widely accepted principle in international society, it is a matter of international concern and could not be regarded as an exclusive internal problem." 
10. Requests the Secretary General to approach the Technical Support Facility of the Group of Fifteen (G 15) to explore possible areas of co-peration with the Asian African Legal Consultative Committee as far as the legal aspects of the right to development are concerned, and to report to the Thirty Fourth Session on the outcome of this consultation;

11. Directs the Secretariat to make further studies on the development of international law in the field of human rights, and render appropriate legal assistance to the member States at their request in connection with national legislation concerning the promotion and protection of human rights".

\section{4. 'Agenda for Peace'}

63. The Committee had before it a document prepared by the Secretariat entitled Agenda for peace: preventive diplomacy and related matters (Doc. No. AALCC/XXXIII/94/8) which contained a summary of the Report of the UN Secretary-General circulated to Member States of the United Nations as document $A / 47 / 277$ in response to a request by the UN General Assembly in 1992. The document recalls that AALCC at its Kampala Session in 1993 had established an open-ended working group with a core membership of Egypt, China, Ghana, India, Indonesia, Japan, Nigeria, Qatar, Saudi Arabia, Tanzania and Uganda, to examine the Report and assist the Secretariat to prepare a study to be submitted to the United Nations on the occasion of its Fiftieth Anniversary. The Secretariat document suggests work on two topics: (1) legal problems associated with the removal of mines left in former areas of conflict including, most recently, Somalia, Mozambique, Cambodia, Angola, Afghanistan and Yugoslavia, with the aim of developing an international convention on 'de-mining'; and (2) legal problems involved in maintaining the security and safety of international personnel engaged in peace keeping and other humanitarian activities, with the aim of developing an international convention on the subject.

64. The Secretary-General of $A A L C C$, introducing the item, said that while the United Nations could and should play a pivotal role in matters concerning international peace and security, it was important that the delicate balance established by the Charter among its various organs should not be disturbed. The Security Council should not, he said, usurp the powers and functions of the General Assembly, and the role of the International Court of Justice in dispute settlement should be enhanced. Moreover, regional organizations could play an important role in bringing peace to their respective areas. He sought 
the Committee's mandate to commence work on the two topics mentioned in the Secretariat document.

\section{Decision}

65. After discussion of the item (Report, pages 106-110) the Committee adopted a Decision (Report, page 237) in which, inter alia, it took note of proposals for future work, and directed the Secretariat to consider initiating a joint programme in co-operation with the International Committee of the Red Cross and other organizations engaged in similar work.

\subsection{Debt burden of developing countries}

66. The Committee had before it a document prepared by the Secretariat entitled Debt burden of developing countries: an overview of recent developments (Doc.No. AALCC/XXXIII/ TOKYO/94/14) outlining the impact of some recent debt reduction and debt management strategies.

\section{Decision}

67. Having considered the document before it and an introductory statement by the Assistant Secretary-General (Report, pages 150-1), the Committee adopted a decision (Report, pages 246-7) which, inter alia, expresses concern at the growing burden of debt and debt service as major obstacles to the revitalization of growth among the developing countries, despite the economic reforms undertaken by many of them; calls upon Member States to take additional measures on an urgent basis to reduce official and commercial debt; and urges commercial banks to extend initiatives to overcome the commercial debt problems of the least developed countries and of low and middle income developing countries.

\subsection{Trade Law matters}

68. The Committee had before it the following documents prepared by the Secretariat: Progress report concerning the legislative activities of the UN and other international organizations in the field of international trade law 
(Doc.No. AALCC/XXXIII/TOKYO/94/15); Legal and institutional framework and guidelines for privatization in Asia and Africa (Doc.No. AALCC/ XXXIII/TOKYO/94/16), which was considered by a Special Meeting during the Tokyo Session; Report on progress made by the Data Collection Unit (Doc.No. AALCC/XXXIII/ 94/11); and Progress report on AALCC's regional centres for arbitration (Doc.No. AALCC/XXXIII/94/13).

69. Document No. 94/15 reports on the work of the UN Commission on International Trade Law (UNCITRAL) at its Twenty sixth Session (1993) focusing on the Model Law on Procurement of Goods and Construction adopted by it; outlines the work programme for the triennium 1993-5 of the Institute for the Unification of Private Law (UNIDROIT) approved by the General Assembly of UNIDROIT in December 1992; surveys the work of the UN Conference on Trade and Development (UNCTAD) in the field of trade law, covering renegotiation of commodity agreements, and developments concerning promotion of the transfer of technology, control of restrictive business practices, and maritime and multi-modal transport; describes the work of UNIDO in preparing investors' guides (e.g. Hungary, Tanzania), studies dealing with trends in international product standards and the implications for the developing countries, guides on industrial subcontracting, and a manual on technology transfer negotiations; and notes some of the topics to be taken up by the Hague Conference on Private International Law, including conflict of laws problems arising with regard to bank guarantees, civil liability for environmental damage, and recognition and enforcement of foreign judgements.

70. Document No. $94 / 16$ is a 'conference paper' prepared for the Special Meeting on developing legal and institutional guidelines for privatization and post privatization regulatory framework which took place under the auspices of the Committee from 18-20 January 1994. The document outlines the history of public sector enterprises in the developing countries; recalls growing dissatisfaction with their performance; provides an overview of privatization programmes in Egypt, India, Indonesia, Japan, Malaysia, Nigeria, Pakistan, Philippines, Republic of Korea, Sri Lanka, Thailand, Turkey, Tanzania and Uganda including a list of the relevant national legislation; summarizes points of comparison among the different programmes concerning objectives, strategies, scope, social aims, conditions attached to privatization, planning, institutional machinery, and methods and procedures of implementation; and makes observations concerning the legal and institutional framework for 
privatization. The Report of the Special Meeting, transmitted to AALCC for its consideration, contains the following 'paper':

\section{"Legal Guidelines for Privatization Programmes}

\section{Introduction}

1. The objective of this paper is to provide guidance to policy-makers in addressing legal issues likely to arise once a governmental decision has been made to proceed with a programme for the privatization of state assets or enterprises. Such a programme may entail the privatization of substantially all state enterprises in the tradeable sectors of a country, sectoral privatization or the privatization of selected medium or large enterprises. The paper does not, however, discuss small scale privatization of the retail or service sectors or mass privatization programmes involving the distribution to the general public of vouchers or similar instruments.

2. 'A privatization transaction' for the purposes of these guidelines is one in which ownership or control of a public body (state, government, ministry, department, enterprise or corporation) or its major assets or shares held by a public body in a company representing a controlling interest are to be transferred from the government or a government-controlled entity to the private sector.

3. 'Private sector' would exclude an entity which is owned or controlled, directly or indirectly, by a public body. So the sale of an enterprise to a public body, whether of the host state or another state, is not a privatization for the purposes of these guidelines.

4. A privatization law serves a valuable purpose in defining the legal authority for a country's privatization program, the key principles on which it will be based, and the institutional arrangements for policy making and implementation. Other supporting laws provide for the legal steps in preparation for privatization and to consummate the transaction, as well as forming part of the business environment in which the newly privatized enterprises will operate. 


\section{Privatization Law}

5. The choice of whether or not to enact a privatization law depends upon the legal and individual circumstances of the country concerned. In some cases, a privatization law to authorize the sale of state assets may be a constitutional requirement. Even if a separate privatization law is not mandatory, such a law can serve a variety of purposes, such as to:

- define the government's objectives and establish commitment to the privatization process;

- make amendments to existing laws which otherwise would be an obstacle to privatization, e.g. laws preventing private sector participation in what were previously thought of as 'strategic' activities;

- create institutions with the authority to implement privatization: avoid the 'vacuum of authority' which can lead to spontaneous or unauthorized privatization;

- $\quad$ allow for the financial restructuring of enterprises prior to sale and permit liabilities to be cancelled, deferred or swapped for equity;

- define the methods of privatization and any limitations on potential bidders; and provide for the allocation of sale proceeds.

6. A principal function of a privatization law is to define the scope of the program and any exclusions of specific sectors or enterprises. Though the law may list the enterprises to be privatized, the disadvantage of doing so is that the listing becomes inflexible, with the resulting difficulty of either removing or adding enterprises as the program evolves. Other alternatives are to:

(a) adopt a 'negative list' approach, so that all state enterprises are eligible for privatization other than named exceptions, or

(b) require a high level political decision on a case by case or sectoral basis to transfer an enterprise to the privatization agency for disposal.

7. The privatization law can provide for employee preferences to be available on the sale of an enterprise. Preferences should be in the form of a right to acquire a small proportion (normally not more than 10 per cent) of the shares of the enterprise. Payment may be deferred for a limited period, with transfer of ownership of the shares delayed until payment bas been made. Employee consortia should also be eligible to participate in the full bidding process on a basis of parity with other bidders.

\section{Other Supporting Laws}

8. The legal framework of the country should support privatization in two respects; first, laws may be required to govern the process of preparing enterprises for privatization and undertaking the transactions, and second, the 
overall legal environment must be one in which the newly privatized businesses can obtain access to land and finance, enter into enforceable contracts for their inputs and outputs, and compete on a basis of equality with one another and with the residual state sector.

9. The conversion of enterprises into corporations under a modern corporations law is an effective prelude to privatization. Corporatization enables the assets and liabilities of the business to be identified, allows for the appointment of a transitional board of directors to oversee the management, and provides for the issue of shares to the government, allowing flexibility in the sale of partial interests if required. The corporations law should also include procedures for the liquidation or dissolution of enterprises, thereby releasing the assets of a corporatized state entity for sale to the private sector.

10. Prior to the sale of certain heavy polluting enterprises, it would be advisable to perform an environmental audit of those industries to determine the requirements for any environmental and occupational health cleanup. This audit can be performed in accordance with any existing domestic or international environmental and occupational health standards. Based on that audit, the seller can decide whether to absorb the costs of existing environmental degradation, while requiring the buyer to meet future environment liabilities.

11. Labor restructuring is commonly required before privatization to reflect the change from a government agency to a profit oriented enterprise. Labor laws should define the entitlement of redundant employees to severance or other benefits, while recognizing the right of the employer to reorganize the labor force to meet changing needs.

12. Privatized enterprises are most likely to operate efficiently when they are exposed to competitive forces. A competition law is desirable to:

- allow for the review of the potential cartel effects of purchase of former state enterprises by domestic or foreign entities with market power in the same or related sectors,

- prohibit restrictive or unfair trade practices.

If the enterprise is a public utility, a regulatory regime should be created by law so that the regulator can protect the public interest in output pricing and the quality of services and support future entry by competitors.

13. If foreign investors are expected to participate in the privatization program, the laws of the country should guarantee fair and equitable treatment to those investments according to generally acceptable international standards. 


\section{Institutional Arrangements}

14. Privatization requires institutional arrangements to manage the program that ensure transparency and consistency in implementation.

15. Yet the conduct of privatization transactions differs from traditional bureaucratic activities, in that:

(a) the process must be as open as possible;

(b) privatization cuts across existing areas of influence and political and bureaucratic control;

(c) the agency controlling privatization must itself operate in a professional manner, as it will be dealing with private domestic and foreign buyers and with investment banks and other professional advisers.

16. These factors suggest the need for a central unit or agency responsible for overall guidance of the privatization program. The agency should have a single mandate, to sell the assets and enterprises in accordance with the policy principles on which the program is based. A clear mandate to privatize, sufficient autonomy, minimal bureaucracy, ready access to top decisionmakers, and a small nucleus of quality staff are conditions for success. Responsibility for managing the enterprises prior to sale should rest, if possible, with the governing board of the enterprise.

17. The agency should desirably be given sole authority to:

- recommend to the appropriate political decision-maker the enterprises or classes of enterprise to be included in the privatization program;

- decide upon any necessary financial restructuring of the enterprise prior to sale;

- determine the timing and method of sale;

- control the preparation and issue of bid invitations and the prequalification of bidders, if required;

- require government-appointed members of the governing board of each enterprise to resign at or prior to settlement of the sale; and

- recommend the acceptance of the winning bid.

18. Though design, policy-making and supervision of the process is best centralized, transaction management and implementation should be decentralized to accelerate the process and reduce the workload of the central unit. Responsibility for implementation can be delegated to holding companies or institution-specific groups of experts and stakeholder representatives, assisted by investment banks, lawyers or other professional advisers as required. 


\section{Transparency}

19. Transparency must be maintained in every privatization transaction. This can be ensured by having a precise, detailed and publicly announced process for carrying out privatization transactions consisting of clearly defined competitive bidding procedures, clear and simple selection criteria for evaluating bids; disclosure of the final purchase price and buyer, well-defined institutional responsibilities; and adequate monitoring and supervision of the program.

20. Lack of transparency can lead to a perception of unfair dealing - even where it does not exist - and to criticism that can threaten not only privatization, but reform in general.

21. Competitive bidding ensures both transparency and fairness and can help maximize sales proceeds if qualified bidders participate and if the process is properly structured and carefully implemented. The dual objective of competitive bidding is to draw all potential buyers into the bidding process, and to avoid the risk of collusive dealing (or the appearance of it) inherent in closed bidding procedures. Competitive bidding also eliminates the need for the seller to devote time and resources to obtaining a market valuation of the assets to be sold.

\section{Methods of Privatization}

22. The choice of the method of privatization would be determined, in the case of each transaction, according to the following main criteria:

(a) the objectives pursued by the government;

(b) the enterprise's performance record and economic prospects;

(c) the size of the company to be sold and the ability to mobilize private funds, whether from a core domestic or foreign investor or from the general public.

23. Even within the same transaction, a variety of privatization methods may be used, for example, sale of a tranche of shares to employees, followed by the sale of a core shareholding to a long-term investor, and finally a public offering of the balance of the shares.

24. For the sake of transparency, to minimize the influence of special interests and to protect the integrity of the privatization program, the choice of privatization methods should normally be limited to:

(a) sale of assets or shares through public auction or tender;

(b) public offering of shares on the stock exchange;

(c) employee/management buy out; 
(d) concession, lease or management contracts; or

(e) a mix of these four methods.

Subject only to existing legal obligations, such as preemptive rights of existing shareholders, no direct sale or negotiation with a single party should occur, except after the failure of a public bid process, and then only with the approval of a high level government body such as the Cabinet or Council of Ministers.

25. The following paragraphs provide general guidelines for the sale of assets through public auction or tender and through public offering of shares.

\section{Public Auction and Public Tender}

26. The public auction technique should be reserved for selling individual assets, such as land, cars, and pieces of equipment and similar assets as well as small or less important businesses. It consists of convening a public forum at a pre-specified date and location at which one or more companies or simple assets are bid upon by interested, and sometimes, prequalified buyers and sold to the highest price bidder. The process of sale mandates that the assets or companies to be sold are described in public announcements and the opportunity to inspect the assets prior to the auction is allowed.

27. In contrast to public auction, public tender is usually in the form of a sealed bid submitted to the managers of the tender process. Preparation of the request for bids requires careful thought and attention to be certain that the concerns which the government may wish bidders to address, are specified. The general principles for a public tendering process are:

(a) the tender notice should be widely publicized and should provide summary information on the assets, should fix the date of bidding and should invite prospective bidders to obtain the tender document;

(b) interested parties should submit letters of interest to receive the tender document and should be invited to visit the enterprise being sold to inspect its operations and finances;

(c) bids should be sought on a cash basis, accompanied by a deposit;

(d) bids should remain valid for a period after the closing date to allow careful evaluation and possible negotiation with the top bidder; and

(e) the privatization agency should have the right to reject any bids which do not conform to the general bidding guidelines, or to reject all bids if none are adequate.

28. The criteria for evaluating the tenders received could differ from one case to another. Desirably, tenders would be evaluated solely on the basis of price, i.e. the cash and other financial aspects of the bid (such as the assumption of 
liabilities by the bidder) would be assessed on a net present value basis, using a standard and consistent discount rate. The highest value bid would be selected.

The inclusion of non-price criteria can be justified in certain cases, though the bid evaluation process is made more complex. Examples of possible criteria are:

(a) Consistency with privatization principles and objectives

- New capital investment proposed in the bidder's offer;

- The bidder's commitment to continue operating the business;

- Extent to which the proposal offers job protection or retrenchment to employees;

- Budgetary impact;

- Bidder's intention to offer expanded or related services; and

- Bidder bringing in foreign exchange for the investment.

(b) Operational considerations and constraints

- Feasibility of the bidder's proposed business plan;

- The financial standing of the bidder;

- Aspects related to contract implications, asset transfers, personnel transfers and the transitional implications to the government;

- Costs related to environmental cleanup.

30. Non-price criteria should as far as possible be dealt with in the prequalification process to avoid the need to attribute financial 'freights' to these factors. When factors such as investment or employment maintenance promises are included as tender criteria, rather than simply pre-qualification assurances, it will be necessary to include legally binding terms to give effect to these promises in the contract with the successful bidder. The privatization agency would also need to maintain an effective monitoring and enforcement capacity during the post-privatization period.

\section{Public Offering of Shares}

31. Approval of an offering prospectus by the relevant capital markets authority according to its normal requirements and criteria, contained in the securities market law, is necessary before any public offering of shares can be made. Steps for public offering of shares typically include:

(a) preparation of the prospectus, which should include relevant information concerning: the price; a detailed description of the securities offered; the use of the proceeds from the issue; the plan of distribution of the securities; the risk factors that the investor should take into account, the business of the company; its legal and financial structure; a description of its main assets and important pending legal proceedings. The prospectus 
would also contain audited historical financial statements of the most recent three years and state the name of the auditor. The prospectus should be full, true and clear so the investor has all relevant information necessary before making a decision whether or not to buy the securities being offered;

(b) determination of offering price and timing of sale;

(c) organization of a selling campaign and distribution of the prospectus as widely as possible; and

(d) distribution and collection of applications for buying shares.

\section{Allocation of Proceeds}

32. When state assets are sold, the general budget law may determine how the sales proceeds are to be dealt with. If the existing laws do not do so, the privatization law itself should specify that proceeds should be applied:

- first, to meet the costs of sale, which may include a fixed percentage of the proceeds as a contribution to the operating costs of the privatization agency;

- second, towards liabilities of the enterprise retained by the state;

- third, towards outlays which benefit the economy at large or large segments of the population.

33. Since the restructuring of enterprises for privatization can frequently lead to one-time labor costs for the severance and retraining of redundant labor, a fixed proportion of the amounts remaining after payment of sale costs and enterprise liabilities may be applied to a special fund set up for this purpose.

\section{The Privatization Transaction}

34. In addition to the broad local issues having application across the entire privatization program, individual privatization transactions will give rise to a variety of legal issues needing to be dealt with on a case by case basis in reliance upon legal advice.

35. Specific transactional legal issues are most readily resolved in the context of a clear and consistent set of publicly announced guidelines for each step of the process, from evaluation through implementation. These guidelines should include the following principles:

(a) Public enterprises should be divested into markets open to competition. For public enterprises operating in commercially oriented sectors, purchasers should not obtain an intact or unregulated monopoly and should not be accorded special protection or privileges such as market protection, concessional or differential input prices, public sector financing, loans or loan guarantees. 
(b) All appropriate regulatory issues should be dealt with prior to or simultaneously with privatization. In the tradeable, commercially oriented sectors, regulatory provisions entailing the deregulation/liberalization of imports, prices and market and the removal of other barriers to competition should be introduced. In the non tradeable, utilities sectors which generally require large investment (such as electric power and water supply), the establishment of regulatory mechanisms dealing with entry and pricing policies is essential to ensure the confidence of private investors, and to protect the interests of users.

(c) In cases where the government retains a minority shareholding, it should not be entitled to any special or extraordinary voting rights, except in certain cases in the 'strategic' non tradeable sector, where a golden share could be retained. Such a golden share could permit the government to veto the resale of a controlling interest if that would not be in the interests of the country.

(d) The consideration received by the government in a privatization transaction should be cash or the assumption of public debt (in the case of debt conversion). Where shares are to be transferred to the workforce of the enterprise and are to be paid for over time, the government should receive payment for those shares in full at the time ownership is transferred. The ultimate beneficiaries may finance their share purchase from the financial markets in such manner as they may arrange, or alternatively the shares may be held by a trustee until payment has been made.

(e) There should be no restrictions on participation (local or foreign) either as owner, manager, shareholder or otherwise in the privatization process. The government may however decide, as an exception, to reserve a tranche of shares for domestic investors only."

71. Document No. 94/11, describing progress made by the Committee's Data Collection Unit, financed by the Republic of Korea, notes that the methodology adopted in setting up the Database, classifies information on the Legal Framework for International Trade by subject within the following categories: (a) standard/model contracts for use in international trade; (b) legal guides; guidelines and model laws; (c) legal framework for foreign investment; (d) trade expansion, economic co-operation and integration; (e) intellectual property rights; (f) exchange control arrangements and exchange restrictions; (g) countertrade; (h) arbitration; and (i) international conventions in the field of international trade. Listing documentation thus far received, the Secretariat urges greater co-operation on the part of Member States, referring to difficulties in processing the information transmitted due to its piece-meal character, language differences, and the Committee's lack of the necessary staff. 
72. Document No. 94/13 contains a survey of the activities of AALCC's regional arbitration centres at Kuala Lumpur, Cairo and Lagos, and notes plans to establish similar arbitration centres at Tehran and Nairobi. Also before the Committee at its Tokyo Session was a separate detailed description of the activities of the Cairo centre, eventually included as part VIII of the Report (pages 185-223) on the Session, to which are annexed sets of "Principles adopted by arbitral tribunals in awards issued under the auspices of the Cairo Regional Centre for International Arbitration" (Report, pages 201-6) and 'Rules for Mediation' (Report, pages 207-215) as well as a 'Code of Ethics' for arbitrators (Report, pages 217-219).

\section{Decisions}

73. Having considered the documentation before it, and the Deputy SecretaryGeneral's introductory statement (Report, pages 99-100), the Committee adopted essentially procedural decisions with respect to the item generally (Report, page 249), and to the work of its regional centres for arbitration (Report, page 245).

74. In a separate decision on the work of UNCITRAL (Report, page 253), the Committee, inter alia, welcomes adoption of the Model Law on Procurement of Goods and Construction, urging Member States to take it into consideration when enacting or revising laws on procurement, and

"4. Urges the Member States which have not done so to consider adhering to the United Nations Convention on the Carriage of Goods by Sea, 1978 (Hamburg Rules) since wider acceptance of the Hamburg Rules would result in a better protection of shipper's interests, and an early replacement of the Hague and Hague-Visby Rules by the Hamburg Rules would promote uniformity in this vital area, . ."

75. In a separate decision (Report, pages 251-2) on the Report of the Special Meeting on Privatization, the Committee, inter alia,

“. . .

4. Endorses the contents of the Report which faithfully describes the dis-

\footnotetext{
${ }^{3}$ The delegate of Japan made the following reservation with respect to this decision: "My delegation has joined the consensus on the Draft Resolution on the work of the UNCITRAL, with the understanding that para. 4 of this resolution in no way affects the freedom of each State in adhering to the Hague-Visby Rules."
} 
4. Endorses the contents of the Report which faithfully describes the discussion during the meetings on vital legal issues on privatization;

5. Commends the Report which contains the text of the draft legal and institutional guidelines on privatization and post privatization regulatory framework already appended to the Report for consideration of member states;

6. Requests the Secretary-General to endeavour to obtain funds from the World Bank to publish and give broad publicity as expeditiously as possible, the proceedings and Report of the Special Meeting including the guidelines annexed thereto to ensure its widest dissemination throughout the Afro-Asian region."

\section{OTHER MATTERS}

\section{Deportation of Palestinians in violation of international law, particularly the Geneva Convention of 1949 and the massive immigration and settlement of Jews in the occupied territories}

76. The Committee, having heard statements by, inter alia, delegates of Palestine (Report, pages 79, 110) and Iran (Report, page 75), adopted a decision $^{4}$ whereby it

\footnotetext{
${ }^{4}$ The delegates of Iran, Japan and Singapore made reservations with respect to this decision, as follows:

Iran

"My delegation does not recognize the accord between PLO and the other party, and while seeking the full realization of the inalienable rights of the Palestinian People, would like to put on the record its reservation on some paras of this resolution which refer to this accord."
}

\section{Japan}

"Since the Committee met in Kampala last year, a historic event took place in the long history of the Middle East Peace Process. On the 13th September, 1993 "Declaration of Principles" has been signed between PLO and Israel at White House, Washington in the presence of PLO Chairman Yassar Arafat and Israeli Prime Minister Ishaq Rabin. Japan strongly supports this peace process and the agreement reached between PLO and Israel. The Japanese Government maintains the position that deportation in question is not justifiable under the international law. However, the issues taken up in this draft resolution, including the question of deportation of Palestinians are now being negotiated as a part of its peace process between the parties concerned. Since the peace process is at a very crucial and sensitive juncture, we believe that the Committee, as a forum of legal experts, should not take a decision which may prejudge the on-going negotiations. For this reason, the Japanese delegation reserves its position on the resolution as a whole."

\section{Singapore}

"Singapore takes the view that this draft resolution does not fall within the purview of the AALCC. The AALCC is a Legal Consultative Committee, constituted to provide an advisory role 
“. . .

1. Expresses its concern at the continuing denial and deprivation of the inalienable legitimate rights of the Palestinian people including, inter alia, the right of self determination, return and the establishment of an independent state on their national soil;

2. Supports the just cause of the Palestinian people and their struggle for self determination and freedom;

3. Condemns Israel's policy in the Arab occupied territories and the deportation of Palestinian people from their indigenous homes and demands the repatriation of all Palestinians deported since 1967 in flagrant violation of Geneva Convention and the Declaration on Human Rights;

4. Strongly condemns Israel's policy of immigration and the Settlement of Jews in the Palestinian and other Arab occupied territories in Golan heights and South Lebanon, and consider it an obstacle towards erecting a just and comprehensive peace;

5. Demands that Israel respect the principles of International Law and all International Conventions which have a bearing on these matters, including the release of prisoners and detainees in Israel jails and concentration camps;

6. Condemns Israel's policy of appropriation and illegal exploitation of the natural resources (particularly water) and the archaeologicalexplorations of the occupied territories in contradiction to the principles of permanent sovereignty over natural resources;

7. Welcomes the signing of the Accord of Principles between the Palestine Liberation Organization and the Government of Israel and considers it an important breakthrough and a first step towards erecting a just, durable and comprehensive peace in the Middle East.

8. Calls on Israel to expedite its withdrawal from the Gaza and Jericho areas to enable the PLO to establish Palestinian National Authority over these territories;

9. Requests member States as well as other states and UN organs to extend moral and material support to the Palestinian National Authority in Gaza and Jericho;

10. Requests the Secretary-General of the Committee to continue to monitor the events and developments in the occupied territories of Palestine; and

11. Decides to include the item in the agenda of its 34th Session."

to Member Governments on various international legal issues. A political statement such as the Palestinian draft resolution is not appropriate for consideration in this forum; it is more appropriate to be considered in a political forum such as the UN General Assembly.

Furthermore, no notice was given for the tabling of this draft resolution until this evening. It is not possible for Singapore to fully consider the draft and formulate position." 